\title{
Private SME accounting in Poland. Does bank lending influence their accounting and financial reporting practice?
}

\author{
Anna Białek-Jaworska ${ }^{\text {a1 }}$ \\ ${ }^{a}$ University of Warsaw, Poland
}

\begin{abstract}
Using data from private Polish Small and Medium-sized Entities (SMEs) for 2003-2013, I investigate in this paper the influence of bank borrowing on their book-tax conformity and accounting practices. In order to verify the importance of the link between tax law and the accounts of private firms, I created variables capturing the records according to local GAAP and I separated records in line with tax rules reflecting the impact of tax law on the accounting practices. Besides the book-tax differences measurement proposed by Watrin et al. (2014), I applied Tang's (2015) approach to estimate book-tax conformity that captures permanent and temporary book-tax differences. I find that bank lending increases the book-tax conformity of profitable firms. Tax avoidance applied by borrowers has a lower impact on book-tax differential than in the case of non-borrowers. Moreover, the findings indicate that monitoring by lenders force SMEs to adopt more advanced accounting practices by adhering to the prudence principle. This allows lenders to learn more about the ability of borrowers to repay loans thanks to more informative earnings. However, only $22.5 \%$ of borrowers applied accounting standards that are not recognized by tax law.
\end{abstract}

Keywords: SME, book-tax conformity, private firms, bank lending, Poland

JEL codes: G32, H25, H26, H32, M41

1 Corresponding author: Department of Banking, Finance and Accounting, Faculty of Economic Sciences University of Warsaw, Długa street 44/50, 00-241 Warsaw, Poland; email: abialek@wne.uw.edu.pl 


\section{Introduction}

In this paper I investigate the influence of bank borrowing on SME book-tax conformity and their accounting practices. The transition of Poland from a centrallyplanned, predominantly state-owned economy to one based mainly on private companies, together with the urgent problem of corporate bad debt in the banking system, resulted in limited access to bank loans and a low share of bank debt in the capital structure of private firms. Increasing the opportunity to acquire external funding has required bank system reform and the establishment of a reliable accounting system. However, even after two decades, tax records still play the dominant role in providing financial information for at least $90 \%$ of the business sector in Poland, i.e., for those active firms that do not prepare financial statements due to a lack of accounting books (GUS, 2015). Partnerships (natural persons) are allowed to maintain tax records with no accounting books if their revenues are less than the $€ 1.2 \mathrm{M}$ threshold. Natural person is a legal form of a firm set up by individuals (mostly more than one individual) that is taxed by PIT (personal income tax). More than $90 \%$ of active firms in Poland has got a legal form of the partnership (over 1.5 million entities) (Bank Pekao SA, 2016). Besides them there are almost 3 million of individuals that do business on their own account (self-employed) (registered in the REGON in the Central Statistical Office) (Siudaj, 2015). Most partnerships employ 5-9 employees (microfirms) in Poland. Besides financial, insurance and state institutions, it is solely obligatory for private limited liability companies and joint-stock companies to maintain accounting books in Poland. Thus, the choice of the legal form of a business is correlated with obligatory accounting records and access to bank debt. This is because banks require financial statements to evaluate a loan application. As a consequence, at least in part, the non-financial corporate debt-to-GDP ratio in Poland is still one of the lowest in the European Union, although it increased from $20 \%$ in 1995 to $46 \%$ in 2015.

I look in this paper at the link between tax law and the accounting of private SMEs in Poland, and the impact of bank lending on the extent in which their financial results and taxable income mirror each other (measured by book-tax conformity). I seek answer to the following research questions: Does debt financing provided by banks influence book-tax conformity in private companies in Poland? Additionally, are lenders really interested in high book-tax conformity when they extend debt to borrowers? And, should those lenders demand greater information regarding the loan-applicant's earnings (higher informative earnings)? Taking into account a more active role in management, one could notice that shareholders (or owners) of private small firms rely less on financial statements for monitoring managers. Consequently, it is even more interesting whether monitoring by lenders forces companies to adopt more advanced accounting practices than non-borrowers? Using a panel analysis of data on Polish private SMEs for the years 2003-2013, I investigate how bank lending affects factors associated with private firm book-tax conformity, taking into account 
the impact of accruals, the recognition of transactions based on accounting standards, and the principles of prudence and matching (pensions, provisions for employee benefits and other provisions, and the revaluation of non-financial assets), and separate the recognition of business operations in accordance with tax regulations by: depreciation and amortization, long-term and short-term deferred costs and tax avoidance. Book-tax differential results from the differences between accounting and tax law purposes and approaches to the recognition of costs and revenues. The main sources of book-tax differences are the impairment of assets, valuation at fair value, provision for warranty repairs, foreign exchange differences from the valuation as at the balance sheet date, provisions for employee benefits, interest accrued but not paid, interest due but not yet received, and unpaid wages, etc. These are temporary book-tax differences which are not respected by tax law in the current year, but which will reverse in the following period. Due to the reversal, these temporary book-tax differences are subject to deferred income tax. In contrast, permanent book-tax differential contains tax-exempt income and non-deductible expenses. The first covers tax-free dividend income and grants, whereas the latter mainly includes costs of representation and private placement advertising, catering services, donations, penalties, fines, interest for late payment of taxes and social insurance, and others. There is little empirical research on private firm financial reporting and book-tax conformity, mainly due to the lack of reliable data. With this study, I contribute to the literature by exploiting the fact that bank lenders use financial statements not only to evaluate a loan application, but also to monitor the borrower's financial standing. This allows me to study the impact of bank lending on private SMEs accounting and financial reporting practice in comparison with nonborrowers. Moreover, in Poland, private legal entities are required to conduct accounts both to calculate taxable income and to prepare an annual financial statement.

Book-tax conformity means the links between income tax and financial reporting rules, and to what extent tax rules influence financial accounting measurements. For this purpose, the differences between accounting income and taxable income are used. The taxable income is estimated by taxation divided by nominal tax rate. The larger the book-tax differential, the weaker the relationship between taxable income and accounting income (and the lower the book-tax conformity). I use alternative empirical measures, proposed by Watrin et al. (2014) and Tang (2015), to calculate book-tax conformity on a single-entity level. Because corporate reporting relying on records kept for tax purposes results in lower earnings quality (Hanlon et al., 2005; Hanlon et al., 2008; Plummer \& Tse, 1999; Easton et al., 2009), debt holders lose information of borrowers financial standing as a result of the higher book-tax conformity. While previous studies have typically examined book-tax conformity at international level (largely in relation to earnings management and tax avoidance), my study is among the first to consider the book-tax conformity of private companies from one country and compare the factors determining book-tax conformity between borrowers and non-borrowers out of private SMEs. In Poland, accounts are required 
by corporate income tax law to calculate the taxable income of legal persons. The dominance of accounting books with no deferred tax observed for Polish private companies (74\%) shows that accounting valuation and impairment (not accepted by tax regulation) do not play a substantial role. I find that higher book-tax conformity is constantly associated with an increase in non-bank borrowing, while with an increase in bank debt merely for profitable borrowers (in the model of the total temporary and permanent book-tax differential). Thus, my findings contribute to recent research on the relationship between book-tax conformity and capital structure (Blaylock et al., 2016) which focus on total debt share in the market value of total assets. The results indicate that higher book-tax conformity increased reliance on debt in the corporate capital structure in the U.S. and caused a shift from equity to debt financing. My findings shed new light on the link between increased book-tax conformity and debt share in capital structure, taking into account separate bank debt and non-bank borrowings. This means that, in Poland, private companies with accounting books could improve their access to bank loans by increasing booktax conformity till they remain profitable. The results offer compelling evidence that private firms recognize more conforming income when they are larger and have more tangible assets. Decreases in the book-tax conformity appear significantly related to the use of the accrual method by profitable borrowers (for the permanent book-tax differential), and the use of more advanced accounting practices, adhering to the prudence principle (for the temporary and permanent book-tax differences).

Prior research has shown that information asymmetry between lender and borrower hampers lender readiness to provide finance (Coluzzi et al., 2012) and limits private firms (mainly SMEs) access to bank lending (Beck \& Demirguc-Kunt, 2006; Chua et al., 2011). To assess a firm's credit worthiness, lenders are likely to prefer the most reliable information regarding downside risk and the evaluation of the firm's collateral, as well as financial statements that are useful in assessing the timing and riskiness of the firm's expected future cash flows from existing projects and anticipated investments (Armstrong et al., 2010). However, during the loan agreement, after the loan is granted, banks require reliable and timely measures of financial performance to monitor existing capital investments, resulting in changes in financial reporting. My findings reveal that unprofitable companies (with financial losses) have higher permanent and temporary book-tax differences than borrowers with fewer bank loans. This means that lender demand for information decreases book-tax conformity of borrowers, depending on their profitability. I contribute to the literature not only by providing a deep insight into the relatively unexplored area of behavioral response to changes in the degree of book-tax conformity, but also by analyzing a novel dataset of 30,000 private limited liability and non-public jointstock companies.

The remainder of the paper is constructed as follows: Section 2 presents the main economic reforms Poland underwent during the transition period which shaped the environment for economic activity. Section 3 describes the interplay between tax and 
financial reporting as one of key influences on the development of accounting in Poland. Section 4 provides a literature review and develops hypotheses. Section 5 outlines the research design and explains different approaches to measure book-tax conformity. Section 6 provides the results of the analyses. Finally, section 7 gives the conclusions.

\section{Regulatory Reforms and Bank Lending for Business Sector in Poland}

In the case of Poland, in a historically short-period, very deep and radical reforms made the irreversible turn from a centrally-planned economy and authoritarian political system to a liberal market economy and democratic society possible, which finally led to integration into the global economy and EU membership.

Regulation, including non-transparency, overly-complex taxes, the labor code (excessive employee protection and inflexible contracts) and social insurance contributions, hindered the growth of firms, imposed high costs on small companies and created uncertainty for them (Balcerowicz et al., 1998). Additionally, dominant state or foreign companies enjoyed lower costs of credit compared to new entrants, and were able to potentially "crowd out" new entrants in credit markets (Hussain, 1994). The lack of external sources of finance impeded the development of new private firms and seemingly halted private sector growth. Retained profits were the main source of finance for investments of enterprises in Poland (Balcerowicz et al., 1998). Furthermore, this situation reduced investor and lender demand for financial information, thereby discouraging firms from using advanced accounting. Companies confined themselves to respecting tax regulations and, as a consequence, their accounting books were also mainly based on tax regulations.

Sources of funding are an essential issue for business enterprises. Because of the limited availability of external capital, they invest less, do not use leverage, and grow more slowly (Rajan \& Zingales, 1995). However, in Poland, most of the restructuring programmes envisaged writing off overdue payments to the treasury, the social security system and other forms of subsidy. On the one hand, this weakened financial discipline and raised expectations of the same debt relief and future financial injections. But, on the other hand, the level of public subsidies in Poland was too high - 1.3\% of GDP in 2002 compared to $1.0 \%$ in the EU - with a predominance of hard-to-monitor indirect instruments (Kozarzewski et al., 2004). In 1990-1992, bad debts owed to banks seriously threatened the stability of the Polish banking system. These debts were heavily concentrated in about $10 \%$ of the enterprise sector, with the remaining $90 \%$ of that sector almost debt-free (Gomułka, 1993). In 1993, the Enterprise and Bank restructuring programme was launched, preventing a crisis in the Polish banking system with the help of bank portfolio restructuring and recapitalisation, and bank-enterprise conciliation agreements, in 
addition to improving bank capacity in risk assessment (Kozarzewski et al., 2004). As a result of the afore-mentioned reforms, Poland was (and still remains) one of countries with the least debt-to-GDP ratio for non-financial corporations in the European Union, at $46.1 \%$, while Germany stands at $54.9 \%$, the Czech Republic at $56.6 \%$, and a staggering $90.4 \%$ for Hungary as of mid-2015 (Fig. 1). The Financial Development Index for Poland is around 0.5, and the relationship between financial development and economic growth rate is on the upper incline of the bell-shaped curve (IMF, Sahay et al., 2015). In Poland, during last two decades non-financial corporate debt-to-GDP ratio increased by 26 pp., from $19.9 \%$ at the end of 1995 , to $46.1 \%$ by the middle of 2015 . In the case of the euro area, non-financial corporate debt-to-GDP ratio rose from $51.3 \%$ of GDP at the end of 1997 to $104.8 \%$ as of 30th June 2015. Although in Poland the percentage of companies utilizing banking products to finance their activities is increasing, it is much lower than the EU average (ZBP, 2015, Dobbs et al., 2015). Often, even creditworthy businesses decide not to obtain external capital because of the high costs of bank loans not only financial, but also administrative costs, including an obligation to audit financial statements. Białek-Jaworska and Nehrebecka (2016) show that SMEs in Poland use much less bank credit than their creditworthiness would allow, implementing financial strategies that follow the 'pecking-order' theory.

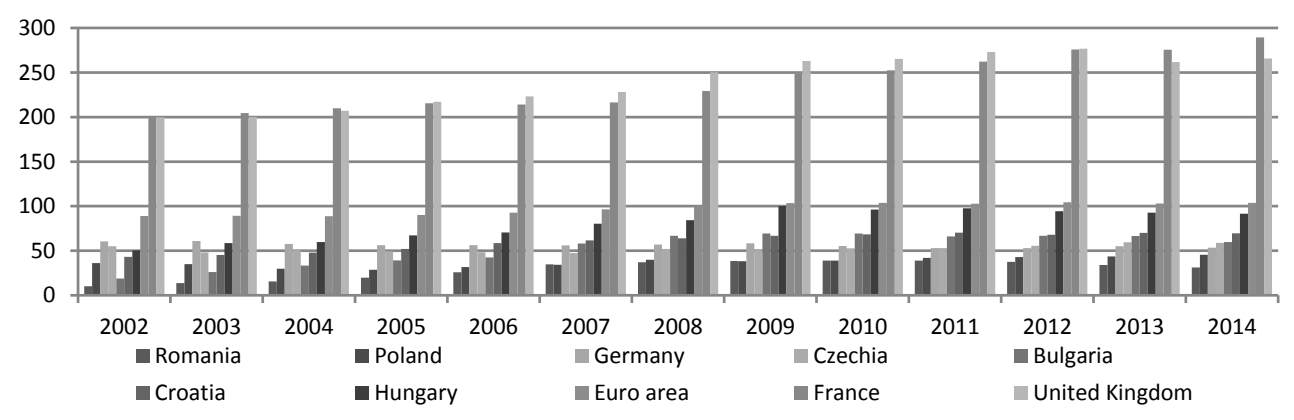

Figure 1. Non-financial corporate debt-to-GDP ratio (\%)

Source: based on the Bank for International Settlements (BIS)

In Poland, only $10 \%$ of active companies do bookkeeping and prepare financial statements (GUS, 2015) needed for the analysis of a loan application. The lack of accounting records and financial statements is a major reason for limited access to bank credit for companies. In this case, the basis for assessing the creditworthiness of a company is the tax returns of the entrepreneur-owner. However, if the owner of the company optimizes its taxation, i.e. commits to paying the lowest possible taxes, and subsequently reports a very low income, this could be a factor that prevents the obtaining of a bank loan. In the case of bank lending to an individual, the bank takes into account the stability of income sources (requiring an employment contract for an indefinite period). While in the case of the analysis of a business loan application, companies are required to present at least a simplified balance sheet and an income 
statement in the absence of accounting records this is not so easy requiring a recording of business operations for their aggregating and the preparing of a balance sheet and income statement. In contrast, companies with accounting books obtain a bank loan on the basis of financial statements prepared on the basis of their accounts, not their tax returns. The low book-tax conformity allows them to obtain a bank loan, despite sustaining a tax loss, or non-payment of income tax due to corporate income tax (CIT) deductible tax losses. The company may deduct tax losses from the tax base for 5 years at no more than $50 \%$ of the losses from previous years in a given year. Data from the Ministry of Finance in Poland indicates that $60 \%$ of companies - potential taxpayers of corporate income tax CIT - do not pay income tax (corporate income tax $=0$ ). This can explain why partnerships also search for an opportunity for tax optimization and tax avoidance.

The involvement of foreign banks in Poland is relatively large compared with euro area countries, although less than in some countries of Central and Eastern Europe. Based on a study of the impact of cross-border banks on financial stability, Schoenmaker \& Wagner (2011) showed that the banking sectors of new countries are dependent on the banks of the old EU countries (EU-15) due to the significant involvement of foreign capital. In recent years there has been a decrease in the average share of foreign capital and an increase in the average measures of concentration.

The comparative cross-country statistics (Fig. 1-3) show that bank finance is less important in Poland than many other countries. Poland has a relatively small banking sector (Fig. 2) with over twice as many bank loans held by households than companies (Fig. 3). SMEs finance most company investment with the use of their own funds (64\%), bank loans, borrowings or leasing (18\%), and funds from foreign sources $(8 \%)$. The greatest involvement of internal funds in financing investments is observed in large companies (73.6\%), decreasing with the transition to a reduced company size, i.e., medium (64.8\%) and small (62.5\%). The number of companies that finance investments through leasing is increasing each year. In 2013, only $7 \%$ of companies benefited from leasing, rising to $11 \%$ in 2014, 13\% in 2015 and again in 2016 to $17 \%$. For the same period, leasing to finance investments rose to $34 \%$ for small companies. This could be explained by the low requirements of financial statements for confirming the financial standing of the lessee. Fourteen percent of respondents to the Panel Polish Enterprises survey conducted by National Bank of Poland indicated there was no possibility to obtain bank loans due to a lack of creditworthiness. By far the most common reason or the self-financing current business operations is the absence of the need to use external funds (54\%), followed by an aversion to debt (28\% in $2015,31 \%$ in 2016). For the remaining $9 \%$ of respondents, equity seems to be cheaper than external financing. 


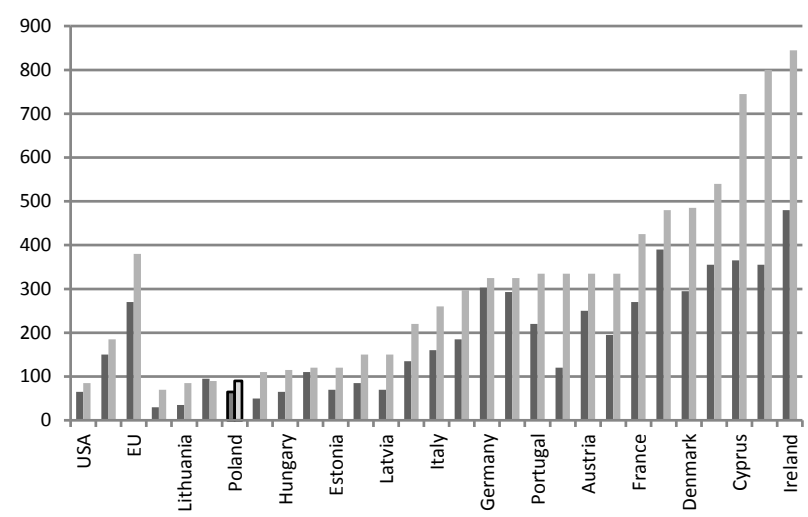

—2002 $\square 2011$

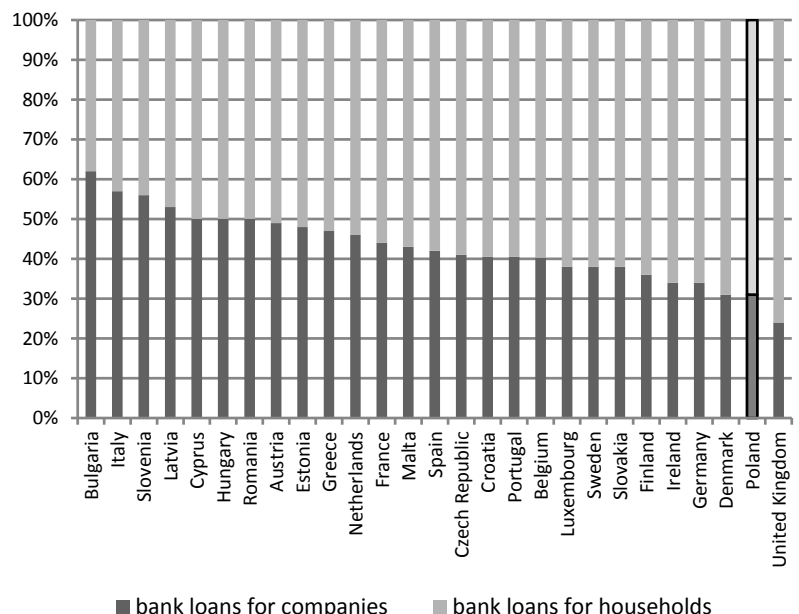

Figure 2. Size of the banking sector of EU members, Figure 3. Structure of loans to non-financial sector in $\%$ of GDP the $\mathrm{EU}$ at the end of 2014

Source: EBC. Eurostat, Bijlsma \& Zwart (2013) elaboration based on

Source: National Bank of Poland the European Central Bank data.

\section{Accounting in Poland - the interplay between tax and financial reporting}

In Poland, the central setting of the reporting model and accounting principles fell within the competence of the Ministry of Finance. The measurement concept was based on the full accrual basis (Nowak, 2015). The core of the Accounting Act has 
its emphasis on disclosure rather than measurement and giving a "true and fair view" of an entity's financial position (wealth and liabilities), and financial performance and profitability. The 1994 Accounting Act introduced cash-flow reporting (solely for larger companies), the concept of deferred tax, business group accounting, and the increased role of the prudence principle through provisions for various risks and contingencies.

However, the interplay between tax and financial reporting is one of the key influences on the development of accounting (e.g. unwillingness to adopt the IFRS). This is because the tax system involves specific principles for recognising revenues and the costs of their realisation, strict principles of fixed assets and intangibles amortization and depreciation, and the adjustment of their value. The 1992 Act on corporate income tax empowered the Minister of Finance to determine, by way of decree, which property elements are regarded as tangible assets and which as intangible, and to lay down the principles of their amortization, depreciation, and value adjustment. The high impact of the tax law on accounting in Poland results in differences in how much the accrual basis is modified, and the method of applying the matching concept. Entities can make only tax closures, but this would result in limited credibility as a consequence of the loss of the neutrality of their financial information (Nowak, 2015). Under high book-tax conformity, tax policymakers are likely to intervene in the standard-setting process (Atwood et al., 2010). In 1999, only $5.7 \%$ of active enterprises did bookkeeping, including primarily legal persons (limited liability and joint-stock companies) (Fig. 4). In 2013 that figure had risen to $10.2 \%$. Although Polish accession to the European Union and the related preparations in the pre-accession period undoubtedly increased awareness of Polish enterprises in terms of the benefits of bookkeeping, in 2001 and 2002 there were still large companies employing over 250 employees that did not maintain accounting books. In 2002, the number of medium-sized entities that did not conduct accounts nearly doubled. This could be due to the amendment of the Accounting Act, which allows enterprises with revenues from sales of goods, final products and financial operations of less than the $€ 800,000$ threshold (in the previous year) to refrain from keeping accounting books. Under the act on natural persons income tax, the limit was the same, but was related to revenues from economic activity. Conversely, it could be due to enterprises adjusting to the "dot.com" crisis (the bursting of the internet technology-related share speculation bubble). After increasing the limit for non-obligatory accounting for partnerships to $€ 1.2 \mathrm{M}$ Euro in 2009 , there were again large companies that did not conduct accounts in 2010 \& 2011, albeit smaller in number. In 2002, 868 medium-sized enterprises (with more than 50 employees) had no accounting records, and in 2004, the year of Poland's accession to the EU, the figure was 539. Prior to the subprime mortgages crisis of 2007, there were 444 entities without accounting records, and 321 companies in 2013 (almost 10\% of the large companies in Poland). The remainder of the business sector that did not keep accounting books, maintained various forms of registers for tax purposes. The most popular of these registers, $49.6 \%$ of enterprises in 1999 and $67.5 \%$ of the business 
sector in 2013, were ledgers of revenue and expense (Fig. 4). These allowed the calculation solely of taxable income, recording revenue (sales of goods and services and other revenue items) and costs (categorised into trade goods and materials at purchasing prices, purchase-related costs and payroll-related expenses and other items).
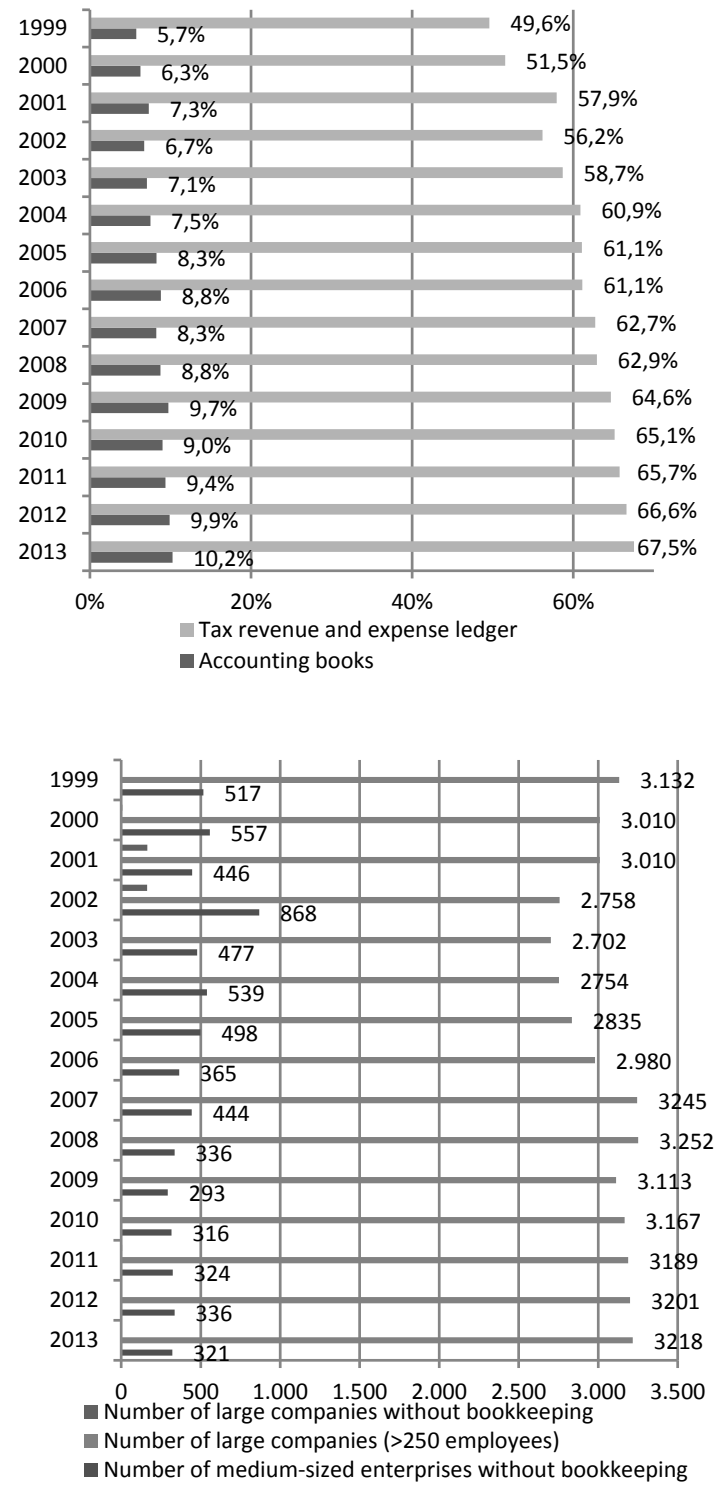

Figure 4. Use of accounting books vs. tax records by the Polish business sector Source: based on the Polish Central Statistics Office database. 
The remainder of the entities recorded only revenue for tax purposes or did not record any revenue or costs due to paying tax in an amount calculated by the tax office according to a tax card (GUS, 2003, 2007; Białek-Jaworska \& Matusiewicz, 2015).

Although Poland has a well-developed legal framework that regulates enterprise sector functionality, the main threat to this functionality is the poor enforcement of existing laws (Kozarzewski et al., 2004), particularly in the scope of private corporate bookkeeping and financial reporting. Hope (2003) explained that environments with a high ownership concentration have low disclosure levels. However, this significant proportion of medium-sized businesses that were not engaged in bookkeeping could be influenced by the development of financial and accounting software to keep tax returns (including ledgers of revenue and expense) with additional tools supporting the management of the company, including records of settlements with suppliers and customers, billings, payments, and even ratio analysis (based on the author's survey of the ERP software offered for SME presented on ICT vendors web sites in Poland, conducted in 2009).

The accreditation of the accounting profession through the requirement to hold a certificate for bookkeeping services, administered by the Ministry of Finance, was abolished on August 9, 2014, (under the law of 9 May 2014) to facilitate access to perform certain regulated professions. By August 2014, the exam or university degree covering the specialisation in Finance and Accounting and completed postgraduate studies in the area of accounting combined with a requirement of 2 or 3 years of professional experience in accounting or auditing, serves as the basis for certification. In 2016 the certification and exams on tax advisor professions still remains and is also conducted by the Ministry of Finance. Tax advisors also have the authority to provide bookkeeping services. The tax advisor statutory competence to provide account-keeping services is more evidence of the significant influence of tax law on accounting practice in private companies in Poland.

According to Art. 9.1 of the Corporate Income Tax Act, taxpayers are required to keep their accounting records in accordance with separate regulations, in a manner which ensures the identification of: taxable income (or loss), tax base, tax due for the tax year, as well as a presentation of fixed assets and intangible assets with information needed to calculate depreciation write-offs. According to Art. 27 of the Corporate Income Tax Act, taxpayers required to prepare a financial report shall submit their financial reports to the Tax Office together with a copy of the shareholders' meeting resolution where the company financial report is approved. Taxpayers required to have their financial report audited shall, in addition, submit the chartered auditor's statement and report within 10 days of the annual report approval. The additional information attached with the financial report shall include a specification of the main items differing the taxable base from the gross financial income.

The permanent book-tax differential results from differences between accounting and tax law purposes and approaches to the recognition of costs and revenues. 
Temporary differences, on the other hand, are caused by the fact that accounting principles and tax regulations do not define in the same way the moment when revenue is generated or a cost is incurred. Accounting books are a source of information for tax-related purposes and are expected to enable the correct identification of taxable income. Figure 5 presents taxable income identification methods: (1) pre-tax accounting income adjusted by expenses and revenues not acknowledged by the tax law or accounting act. The latter includes revenues and expenses that had been excluded from income in previous years, but became revenues and expenses in the current period, e.g. currency exchange differences from the balance sheet valuation in previous years; (2) pre-tax accounting income adjusted by permanent and temporary book-tax differences; (3) taxable revenue over tax deductible expenses (recognized by income tax law). The book-tax differential can be disaggregated into differences that are permanent and those which reverse over time. Temporary (timing) differences arise when an income or expense over time is identical for tax and accounting purposes, but its inter-temporal allocation is different. For that reason, the timing differences are said to reverse, so that their aggregate over all periods is zero. Due to the opportunity for reversal, they are a subject to deferred income tax. The main sources of temporary book-tax differences are: impairment of assets, valuation at fair value, provision for warranty repairs, foreign exchange differences from the valuation as at the balance sheet date, provisions for employee benefits, interest accrued but not paid, interest due but not yet received, and unpaid wages, etc. Permanent differences are tax-exempt income and non-deductible expenses. The first cover tax-free dividends received from other companies and grants. Other examples of permanent book-tax differential with regards revenue include any non-monetary or partly monetary performance, including upward adjustments of real estate purchased below its market value or of any interest-free loans or loans received at below-market interest rates.

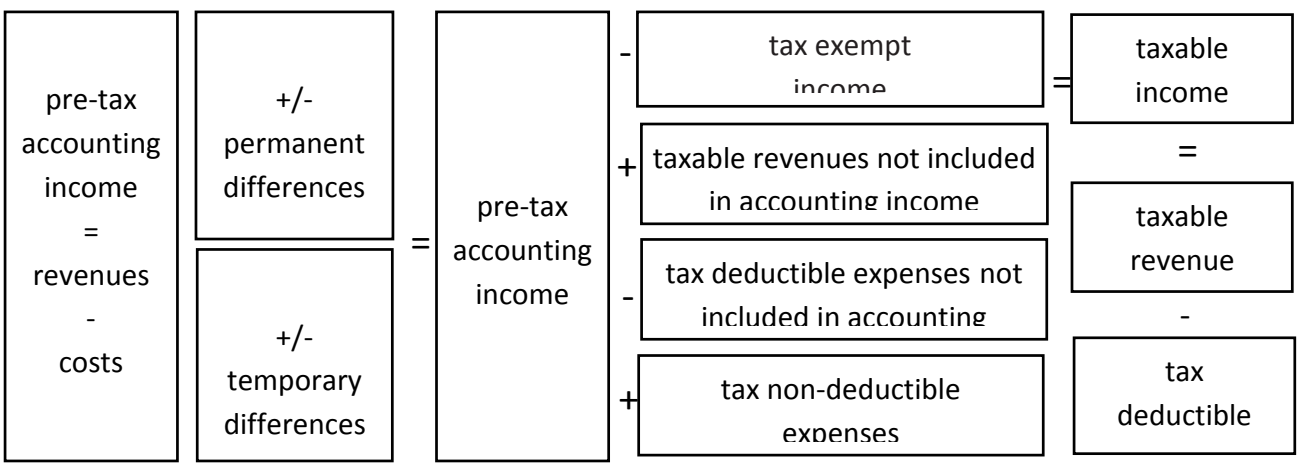

Figure. 5. Reconciliation of the profit before tax and taxable income that will include those differences 
Non-deductible tax expenses contain costs of representation and private placement advertising, catering services, donations, penalties, fines, interest for late payment of taxes and social insurance, and others. Permanent differences are items used for computing taxable income that never comes into the calculation of profit before tax or, more typically, items of profit before tax that never come into the calculation of taxable income. Thus, permanent differences do not reverse. Both timing and permanent differences are indicators of a lack of book-tax conformity. Since the latter is a non-reversing item, it affects the book-tax differential only once. In contrast, the timing difference affects the relationship both when it arises initially and when it reverses.

In almost every country, accounting results are the natural starting point for the computation of taxable income. However, the degree of the connection between taxation and financial reporting greatly differs between countries because of the type and the number of adjustments to accounting profit required by tax law (Gavana et al., 2013). Besides rule differences in the accounting and tax reporting systems, earnings management and tax avoidance are factors that generate a level of book-tax differences that a firm reports (Hanlon \& Heitzman, 2010; Tang \& Firth, 2011, 2012; Wilson, 2009).

\section{Hypotheses development}

My research concentrates on the impact of debt financing on the link between tax law and the accounting (measured by book-tax conformity) of Polish private firms whose shareholders take a more active role in management, reducing their reliance on financial statements for monitoring managers. Private firms are typically more closely held and their shareholder turnover is lower. The financial reporting of private companies is more likely to be influenced by income tax law. Relative to public companies, the demand for financial reporting in private firms arises less from reducing information asymmetry between managers and other stakeholders (lenders, shareholders, suppliers, and customers) and more from tax, dividend, and compensation payment policies (Ball \& Shivakumar, 2005). The influence of tax policy on private firm financial reporting would arise from the lower benefit, relative to cost, of keeping separate tax and financial reporting records. The demand for higher quality in public-company financial statements is reflected in the greater legal obligations of managers and auditors to recognise economic losses in a timelier fashion, and in the litigation costs of failing to do so. Managers and auditors of private firms implicitly or explicitly contract for a lower level of financial reporting quality, and face lower litigation costs in supplying it.

Most studies have assumed that tax regulation influencing accounting income reduces accounting quality (Ali \& Hwang, 2000; Hanlon et al., 2008). Atwood et al. 
(2010) suggest that low book-tax conformity gives management the flexibility to signal important information. Kvaal and Nobes (2012) agree with the view of the majority of researchers that the cost of tax influence on accounting income reduces the information content of financial reporting outweighing the benefit of reduced earnings management. However, low book-tax conformity is associated with higher financial reporting quality because it is caused when managers are forced to provide the sort of financial reporting numbers (e.g. fair values for marketable securities, impairments of assets, and recognized lease liabilities) that are more informative than the numbers used for tax purposes.

Polish GAAP allows fair value for investments in: financial assets, intangible assets, and real estate, and it uses discounted cash flows for leased items, money lent, and corporate bonds issued. These factors might all be contributory explanations for better earnings quality (Kvaal \& Nobes, 2012). Most of these measurements are ignored for tax purposes, which was also noticed by Gee et al. (2010). This results in a lack of book-tax conformity when firms choose such an accounting policy. To the extent that measures of book-tax conformity detect how much tax influences accounting income, the higher book-tax conformity is evidence of the lower quality of financial reporting and lower earnings informativeness.

Hanlon et al. (2005) find that financial-statement-based estimates of taxable income in the U.S. are about $50 \%$ less informative to equity investors than a book income conforming to taxable income. Blaylock et al. (2016) argue that the decrease in earnings informativeness impacts debt holders less than equity holders because of the differences in payoff structures between debt and equity investments. These researchers exploited a natural experiment in the U.S. and found that firms facing an increase in required book-tax conformity (by an enactment of the Tax Reform Act of 1986) increase their leverage relative to other firms by $6.4 \%$ with, the corresponding cost increase of equity capital of $1.1 \%$. These findings are consistent with increases in book-tax conformity raising the cost for firms of equity relative to debt capital, and the subsequent moving away from equity and towards debt financing by these firms. So, I hypothesize that firms are likely to respond to information loss resulting from increased conformity by using more debt in their capital structure.

Lenders are likely to be less concerned about the reduction in earnings informativeness brought about by higher book-tax conformity than equity investors (Plummer \& Tse, 1999; Easton et al., 2009). This results from the primary concerns of lenders, i.e., whether the value of a firm's assets fall below their liabilities (Black \& Scholes, 1973), and whether the borrower's current and future cash flows are sufficient to meet their debt obligations (Jensen \& Meckling, 1976) rather than its value relevance. Because tax rules allow for less managerial judgment than accounting rules, managers may be less able to engage in earnings management, even if they have the same incentives to manage earnings (Hanlon et al., 2005). Here, 
there is a need for more debt financing, as the cost of equity capital is likely to increase the incentive for income smoothing to reduce taxes (Hanlon et al., 2005, 2008). Accounting and taxation rules tend to be more aligned within creditor protection-oriented accounting systems than in accounting systems designed primarily to satisfy the financial information needs of investors (Nobes, 2008). Based on the literature review and taking into account the regulatory and institutional setting (the bank-oriented financial system in Poland), I assume that bank borrowing increases book-tax conformity in Poland, thus:

H1: Bank borrowing is positively associated with book-tax conformity.

Bank loan agreements often stipulate the types of information that must be provided to the lender, both before loan initiation and throughout the life of the loan, including internal financial forecasts inventory aging, payable and receivable schedules, capital expenditure budgets, and others (Begley \& Freeman, 2004). Before providing access to capital, banks-lenders require that entities supply audited financial statements and proprietary information such as business plans, in order to assess the borrower's ability to repay the debt (Armstrong et al., 2010). In accordance with the debt covenant hypothesis, more indebted borrowers may use earnings management to improve their reported results and reduce debt covenant violation to avoid financial penalties, such as the possible acceleration of debt maturity, an increase in interest rates, or renegotiation of debt terms (Bikky \& Picheng, 2002). Sweeney (1994) finds that debt covenant violations lead to an adoption of income-increasing accounting changes so that the default costs imposed by lenders are minimized. Therefore, there could be significant different impact of the gaap_first variable and the tax_first variable on the book-tax conformity of borrowers than non-borrowers.

H2: Borrowers apply more advanced accounting practices than nonborrowers: they more often apply accounting standards and base their recording business operations less on tax law.

Moreover, large book-tax differences are typical for greater tax avoidance behavior (Richardson et al., 2016) and book-tax differences are assumed to reflect tax planning (Armstrong et al., 2012). Tang (2015), Chan et al. (2010) and Atwood et al. (2012) confirmed that higher book-tax conformity is accompanied by less tax avoidance. Politicians and regulators (legislators) in the USA are calling for an increase in book-tax conformity in order to reduce aggressive tax optimization practices adopted by businesses (Blaylock et al., 2016). This could be expected as borrowers' financial statements are subject to audit.

H3: Tax avoidance applied by borrowers has a lower impact on book-tax differential than that of non-borrowers. 


\section{Data and Research Design}

\subsection{Sample}

I used data retrieved from the financial statements of 30,000 private non-financial limited liability companies and joint-stock companies that operated in Poland in the period 2003-2013. To mitigate the influence of outliers, I winsorized all continuous variables at the 1st and 99th percentiles. After these procedures, and as an inclusion in my analyses, explanatory variables based on changes in data from the financial statements between the two subsequent years, my research sample was limited to 162,496 firm-year observations of SMEs spanning 2003-2013. The main results are not affected by winsorization (neither the signs of the coefficients nor their significance change). However, without winsorization I received models with high $\mathrm{R}^{2}$ close to 0.99 and insignificant control variables. Table 2 lists a complete description of variables used in the panel analysis of the book-tax conformity measured with lower book-tax differences. Before conducting the panel analysis, descriptive statistics of variables were determined (Table 3) and the correlation between explanatory variables was estimated. Detailed outcomes of the correlation of the explanatory variables are presented in Table 4.

\subsection{Book-tax Conformity Measures}

In this study I apply two measures of book-tax conformity as dependent variables. The first measurement permbtd ${ }_{i, t}$ was introduced by Watrin et al. (2014) and is based on the absolute values of book-tax difference of firm $i$ in year $t$, scaled by total assets, calculated as: permbtd $d_{i, t}=$ ptbi $_{i, t}-\left(\right.$ taxation $_{i, t} /$ tax $\left._{\text {rate }}\right)$, where $p t b i_{i, t}$ - the value of pre-tax book income of firm $i$ in year $t$; taxation ${ }_{\mathrm{i}, \mathrm{t}}$ covers current and deferred income tax of firm $i$ in year $t$; and the tax rate is the nominal corporate income tax rate in year $t$ equal to $19 \%$ for 2004-2014 and 27\% in 2003. As the second dependent variable, I apply an alternative approach to measuring book-tax conformity $\left(b t d_{i, t}\right)$, proposed by Tang (2015), which captures permanent and temporary book-tax differences of firm $i$ in year $t$ scaled by total assets. This is calculated as: $b t d_{i, t}=p t b i_{i, t}$

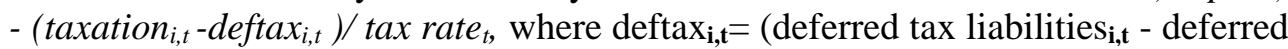
tax assets $\left.\mathbf{i}_{i, t}\right) /$ tax_rate $_{\mathbf{t}}\left(\right.$ the other variables are the same as above). Both the permbtd ${ }_{i, t}$ and the $b t d_{i, t}$ variable indicate that the higher book-tax differential, the lower the book-tax conformity, and, the lower the book-tax differential, the higher the booktax conformity.

In the opinion of Tang (2015), Watrin et al. (2012) overlook the fact that permanent book-tax differences can also be driven by earnings management and tax avoidance (Hanlon \& Heitzman, 2010; Tang \& Firth, 2011, 2012; Wilson, 2009). Therefore, the extent of conformity should be captured by both permanent and temporary booktax differences. This is more important, as I detected that only $26 \%$ of companies in 
the sample had recorded deferred tax to which I was thankful to be able to identify separate temporary book-tax differences. This low share results from the fact that in Poland only companies whose financial statements are subject to audit and are published are required to record deferred tax (according to the Polish Accounting Act, article 37, paragraph 10).

I created two explanatory variables that capture operation records according to GAAP standards (the gaap_first variable), and then separated these records in accordance with the tax rules reflecting the impact of tax law on the accounting practices of private companies (the tax_first variable). In particular, in the case of two-book accounting, while the gaap first category is associated with future taxrelated cash flows that are realised upon reversal of deferred tax assets or liabilities, the tax first category is treated in a different way. New originating temporary differences do not offset the tax effects of reversing temporary differences (Guenther \& Sansing, 2004; Laux, 2013). The gaap_first variable includes the recognition of transactions by the company based on accounting standards and the principles of prudence and matching. This variable, in particular, takes into account pensions, provisions for employee benefits, other provisions, the revaluation of non-financial assets, and, the negative effects of revaluation of financial investments, all deflated by total assets. These operations result in a book-tax differential, as they are not recognized for tax purposes in the current year. In contrast, the tax_first variable measures the recognition of business operations in accordance with tax regulations by: depreciation and amortization, long-term and short-term deferred costs, and other accruals (unearned deferred revenue) in relation to total assets. Earlier studies into the accounting policy of Polish SMEs listed on the NewConnect (an alternative stock exchange) show that the majority of companies use depreciation of fixed assets and amortization of intangible assets in accordance with tax regulations (BiałekJaworska \& Drązikowska, 2015). The items included in deferred costs and accruals are recognized earlier for tax income than for accounting income. 

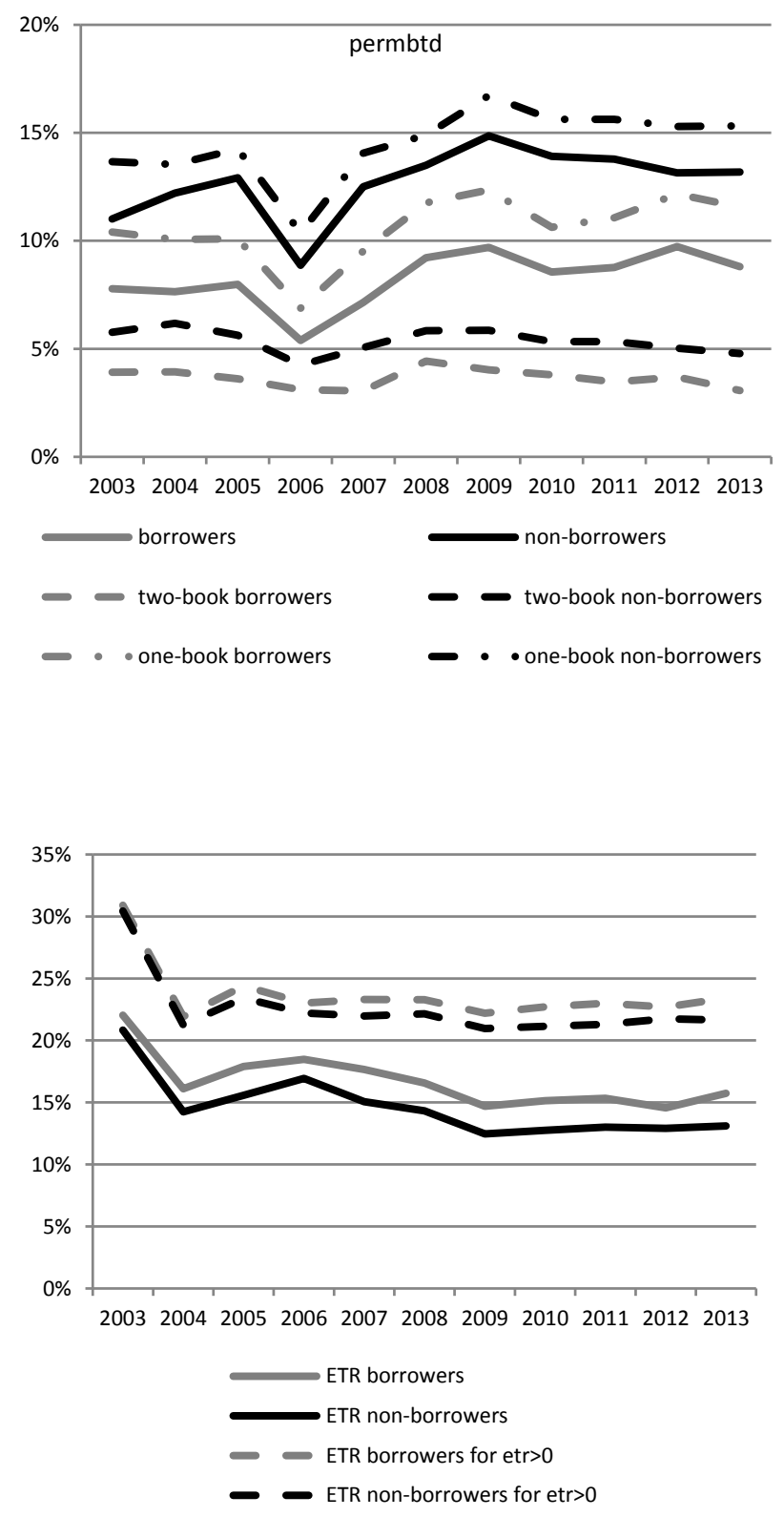


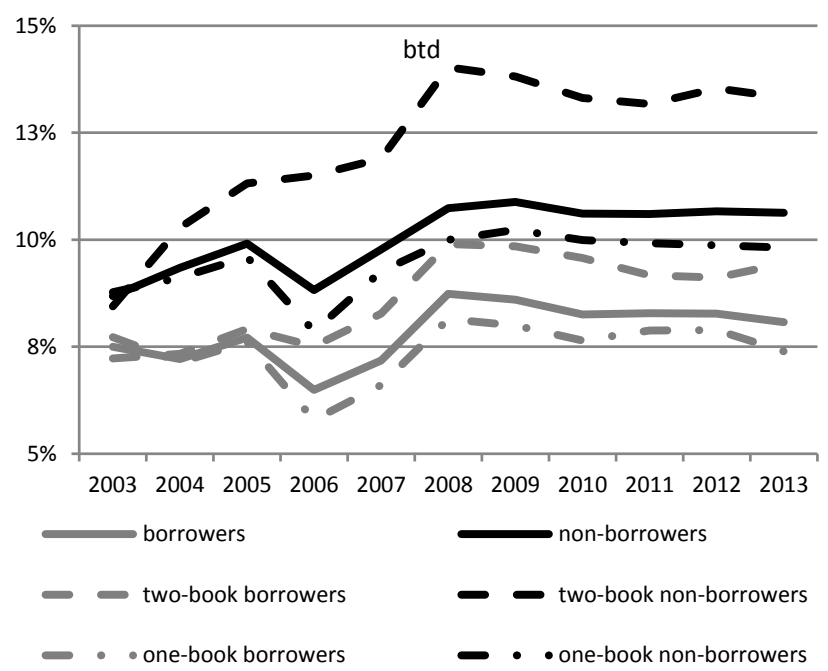

Figure. 6. Comparison of book-tax differences and effective tax rate between borrowers and non-borrowers

In the first figure I measured the book-tax differences as permbtd in accordance with Watrin et al. (2012) concept, while in the third figure I used the measure proposed by Tang (2015) - btd.

The gaap_first and tax_first variables are mutually exclusive, while their correlation coefficient is low (0.0602) for my total sample, and much lower for the one-book subsample (0.0254).

My model also adapts the Dechow (1994) and Guay et al. (1996) approach to incorporate the recognition of unrealised gains and losses via accruals and mitigates noise in cash flows from operations. Accruals are initially measured as a change in inventory, debtors, other current assets less change in creditors, other current liabilities, and depreciation and amortization, scaled by total assets, as follows accruals $=[\Delta$ inventory $+\Delta$ short term receivables $+\Delta$ (other long term deferred costs + short term deferred costs $)-\Delta$ (short term liabilities - short term bank loans and borrowings - short term liabilities due to corporate bonds issue - other short term financial liabilities) - deferred income and accruals - depreciation and amortization] / total assets.

Since the cash basis is more characteristic for tax law than for accountancy, I expect that, as intended by the legislators and regulators, accruals increases book-tax conformity, i.e., this brings the book income closer to the taxable income (reducing the book-tax differential). 
During the whole period of analysis (2003-2013) borrowers had a lower absolute value of book-tax differences for both permbtd and btd measures than companies that had not borrowed money from banks (non-borrowers) in any year. The same relationship, i.e., higher book-tax conformity, was observed for the total sample, both for the one-book and the two-book subsamples between borrowers and nonborrowers (Fig. 6). The highest book-tax conformity is observed for one-book borrowers in the case of the btd variable, while for two-book borrowers it is the permbtd. The lowest book-tax conformity (btd), which decreased till 2008, is characteristic for two-book non-borrowers. The significant differences between borrower and non-borrower book-tax conformity in the total sample, and the separate one-book and two-book subsamples, were confirmed by Bonferroni, Sidak and Scheffe tests after ANOVA analyses (not tabulated here). Additionally, borrowers have a higher average effective tax rate (ETR) than non-borrowers (Fig. 6), which could indicate a less important role of tax avoidance among borrowers.

\subsection{Research Design}

In the study, I use a within estimator for fixed effects regressions of unbalanced panels whose observations are unequally spaced over time. The Hausman specification test fixed versus random effects - indicates to us that I should choose the fixed effect estimator. The Breusch and Pagan Lagrangian multiplier test confirms the significance of random effects. The Wooldridge test for autocorrelation in panel data confirms that there is a problem with first-order autocorrelation AR(1) in the case of the total sample, and, both the one-book and the two-book system subsamples, whereas White's test for homoscedasticity indicates the heteroscedasticity in the panel data. Finally, after the diagnosis of the models, I evaluated them by using a two-step correlation estimation with the Theil fixed effects estimator adjusted for $\mathrm{AR}(1)$ disturbances (Theil type of rho estimator). This approach implements methods found in Baltagi and Wu (1999) that accommodate a variety of patterns of missing data and serially correlated errors of the AR(1) type. This is a form of the generalized least squares (GLS) estimation method that applies a transformation of the data that removes the AR(1) component. This way I receive a two-step efficient estimator. The final results of the fixed-effects regressions are shown in Tables 5-7. In my analysis, I break down the leverage variable into two components: the long-term and short-term bank loan share in the financing of assets (bank_loan) and the non-bank debt financing share in the company capital structure (nonbank leverage). This enables us to analyse how a company's bank debt, and the resultant monitoring by the lending bank, affects its book-tax conformity. The following two panel models were used to analyze the impact of non-bank and bank borrowings and various other company characteristics on the extent of book-tax conformity: 


$$
\begin{aligned}
& \text { btd }_{i t}=\beta_{0}+\beta_{1} \text { accruals }_{i t} \times \text { borrower }_{i t}+\beta_{2} \text { gaap }_{-} \text {first }_{i t} \times \text { borrower }_{i t} \\
& +\beta_{3} \text { tax_first }_{i t} \times \text { borrower }_{i t} \\
& +\beta_{4} \text { non_bank leverage }_{i t} \times \text { borrower }_{i t}+\beta_{5} \text { bank }_{-} \text {loan }_{i t} \\
& +\beta_{6} \text { one_book }_{i t} \times \text { borrower }_{i t}+\beta_{7} \text { TA }_{i t} \times \text { borrower }_{i t}+\beta_{8} \text { control }_{i t} \\
& +v_{i}+\varepsilon_{i t} \\
& \text { permbtd }_{i t}=\beta_{0}+\beta_{1} \text { accruals }_{i t} \times \text { borrower }_{i t}+\beta_{2} \text { gaap_first }_{i t} \times \text { borrower }_{i t} \\
& +\beta_{3} \text { tax_first }_{i t} \times \text { borrower }_{i t} \\
& +\beta_{4} \text { non_bank leverage }_{i t} \times \text { borrower }_{i t}+\beta_{5} \text { bank_loan }_{i t} \\
& +\beta_{6} \text { one_book }_{i t} \times \text { borrower }_{i t}+\beta_{7} \text { TA }_{i t} \times \text { borrower }_{i t}+\beta_{8} \text { control }_{i t} \\
& +v_{i}+\varepsilon_{i t}
\end{aligned}
$$

where:

$b t d_{i t}$ - temporary and permanent book-tax differential as a measure of book-tax conformity, proposed by Tang (2015),

permbtd $_{\text {it }}$ - permanent book-tax differential as a measure of book-tax conformity, proposed by Watrin et al. (2014),

accruals $_{i t}$, gaap_first $t_{i t}$, tax_first ${ }_{i t}$ - alternative measures of book-tax conformity, as described above,

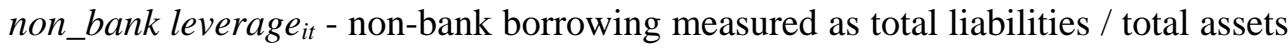
- (long-term bank loans + short-term bank loans) / total assets,

bank_loan $_{i t}$ - bank borrowing equal to (long-term bank loans + short-term bank loans)/total assets,

one_book - a dummy variable equals to 1 when the firm's accounts are kept according to tax regulations with the consequence that there is a lack of deferred income tax. In the other case (one_book $=0)$ companies kept accounts according to accounting standards, and include adaptations stipulated in the tax regulation (two-book). The two-book accounting includes deferred income tax, commonly used for temporary book-tax differences,

$T A$ - the difference between the statutory tax rate and the effective tax rate. The effective tax rate (etr) is the ratio of the current tax expense to gross profit. Etr is truncated to the range $(0,1)$,

control $_{i t}$ - control variables, as described below,

$\beta_{i}$ - constant or coefficients of variables, $v_{i}$ - units' individual characteristics, nonobservable, but constant over time in the case of a fixed-effects model, $\varepsilon_{i t}$ - purely random error.

Book-tax differences, by definition, reflect different reporting requirements for book and tax purposes, i.e., mandatory conformity reflected in the gaap_first and tax_first variables, as described earlier (see subsection 5.2). There is an asymmetry of information provided by these two different categories: the gaap first (associated with future tax-related cash flows) and the tax first category (without offsetting the tax effects of reversing temporary differences) (Laux, 2013). Opportunistic book and tax reporting undertaken by managers also yields variations in book-tax differences (Tang, 2015; Hanlon \& Heizman, 2010). Therefore, I include in this study the 
following as control variables: a firm's property, plant, and equipment deflated by total assets (tangibility that is influenced widely by tax law and in addition plays a role of a collateral for bank borrowings) and the difference between the statutory tax rate and the effective tax rate (a proxy for tax avoidance $(T A)$ ). The effective tax rate (etr) is the ratio of the current tax expense to gross profit. Etr is truncated to the range $(0,1)$. Richardson et al. (2016) consider large book-tax differences as typical for greater tax avoidance behavior. Aggressive tax reporting cannot be directly observable, so measures of tax planning (e.g., tax avoidance) undoubtedly include measurement errors. In the U.S., book-tax differences are assumed to reflect tax planning (Armstrong et al., 2012) while in Poland a large book-tax differential relates more to the legal differences between financial and tax accounting and/or results from a firm's poor financial situation (financial loss or distress). This explains why I analyze separate subsamples depending on the loss dummy variable (i.e., if companies have a positive or negative accounting income after tax). Then I control for firm size (measured by the natural logarithm of the firm's total assets) and return on assets (roa), measured by the ratio of gross profit to total assets (a proxy of profitability). The growth rate of sales is the change in sales from year $t$ - 1 to year $t$ deflated by assets (growth $(\Delta$ sales)). These variables are often used as controls in empirical studies of earnings management. Due to increased public pressure, managers in larger organisations are expected to be less likely to manipulate financial results, which translates into a lower earnings management level (Grabiński, 2016) and, in consequence, higher book-tax conformity. Table 1 explains which part of the above panel model specification is relevant to which hypothesis and indicates the predictions in the context of a book-tax differential used as the dependent variable. In particular, the $\beta_{2}, \beta_{3}, \beta_{5}$ and $\beta_{7}$ coefficients are the basis for testing my hypotheses.

Table 1. Hypotheses and predictions in the context of panel model specifications

\begin{tabular}{|c|c|c|c|c|}
\hline H1 & $\begin{array}{l}\text { Bank borrowing is positively associated with book-tax } \\
\text { conformity (negatively associated with book-tax } \\
\text { differential). }\end{array}$ & $\beta_{5}<0$ & & \\
\hline $\mathrm{H} 2$ & $\begin{array}{l}\text { Borrowers apply more advanced accounting practices (there } \\
\text { is a higher impact of the gaap_first variable and a lower } \\
\text { influence of the tax_first variable on the book-tax } \\
\text { differential) than non-borrowers. }\end{array}$ & $\begin{array}{l}\text { Borrower's } \beta_{2} \\
\text { borrower's } \beta_{2} \\
\text { Borrower's } \beta_{3} \\
\text { borrower's } \beta_{3}\end{array}$ & $>$ & $\begin{array}{l}\text { Non- } \\
\text { Non- }\end{array}$ \\
\hline H3 & $\begin{array}{l}\text { Tax avoidance applied by borrowers has lower impact on } \\
\text { book-tax differential than in the case of non-borrowers. }\end{array}$ & $\begin{array}{l}\text { Borrower's } \beta_{7} \\
\text { borrower's } \beta_{7}\end{array}$ & $<$ & Non- \\
\hline
\end{tabular}

Descriptive statistics show that $76 \%$ of companies in the research sample keep a onebook system and only $24 \%$ keep a two-book system, with deferred tax shown separately in the records (Table 3). The significant impact of tax law on accountancy is confirmed by tax_first being over six times higher than gaap_first. The noticeable difference between the mean (0.0145) and zero median for gaap_first confirms the positive skewness in this variable. This indicates that most firms in Poland follow tax regulations in their accounting books but don't use the fair value estimation, nor 
do they test their assets for impairment at all. Even for the $90^{\text {th }}$ percentile, the effect of valuation according to the accounting policy used is six times lower than that of tax regulations.

Table 2. Definitions of variables used in the panel analysis of the Book-Tax Conformity measured by lower book-tax differences

\begin{tabular}{|c|c|}
\hline Variable & Definition of variables \\
\hline permbtd & 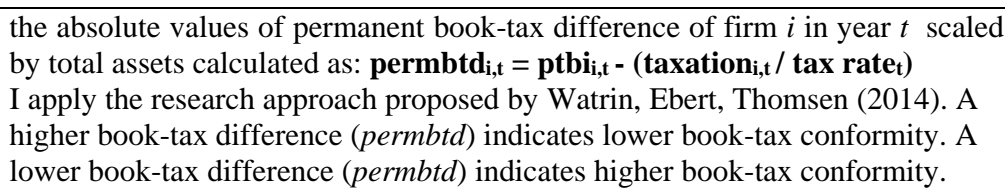 \\
\hline ptbi & the value of pre-tax book income of firm $i$ in year $t$ scaled by total assets \\
\hline taxation & total taxation (current and deferred) of firm $i$ in year $t$ scaled by total assets \\
\hline tax rate & corporate income tax rate in year $t$ equal to $19 \%$ for $2004-2014,27 \%$ in 2003 \\
\hline btd & 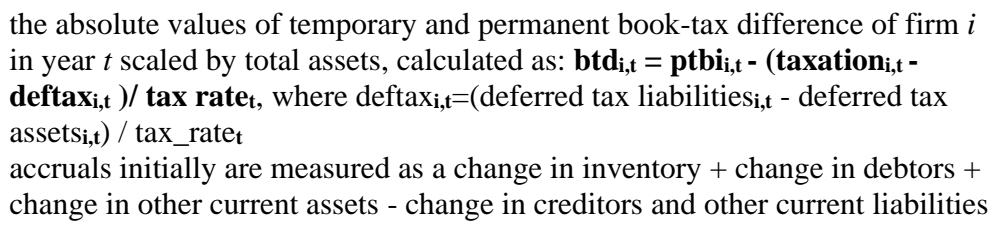 \\
\hline accruals & $\begin{array}{l}\text { - depreciation and amortization, scaled by assets }=[\Delta \text { inventory }+\Delta \text { short term } \\
\text { receivables }+\Delta \text { (other long term deferred costs }+ \text { short term deferred costs }) \text { - }\end{array}$ \\
\hline & $\begin{array}{l}\Delta \text { (short term liabilities - short term bank loans and borrowings - short term } \\
\text { liabilities due to corporate bonds issue - other short term financial liabilities) - } \\
\text { deferred income and accruals - depreciation and amortization] / total assets }\end{array}$ \\
\hline one_book & $\begin{array}{l}\text { system (when there is neither deferred tax assets nor deferred tax liabilities), } 0 \\
\text { otherwise }\end{array}$ \\
\hline two_book & $\begin{array}{l}\text { indicator variable of firm } i \text { in year } t \text { equal to } 1 \text { if a company employs a two-book } \\
\text { system (when there is deferred tax assets or deferred tax liabilities), } 0 \text { otherwise } \\
\text { (pensions (provisions for employee benefits) + other provisions + revaluation of }\end{array}$ \\
\hline gaap_first & $\begin{array}{l}\text { non-financial assets (included in other operating costs) + negative effects of } \\
\text { revaluation of financial investments (included in financial costs)) / total assets }\end{array}$ \\
\hline tax_first & $\begin{array}{l}\text { other long-term deferred costs }+ \text { short-term deferred costs }+ \text { other accruals } \\
\text { (unearned revenue, deferred revenue) }) / \text { total assets }\end{array}$ \\
\hline bank_loan & (long-term bank loans + short-term bank loans)/total assets \\
\hline non_bank leverage & $\begin{array}{l}\text { capital structure of firm } i \text { in year } t \text { after exclusion of bank loans calculated as } \\
\text { total liabilities / total assets - (long-term bank loans + short-term bank loans) / } \\
\text { total assets }\end{array}$ \\
\hline loss & $\begin{array}{l}\text { indicator variable of firm } i \text { in year } t \text { equal to } 1 \text { if a firm reports a loss after tax, } \\
0 \text { otherwise }\end{array}$ \\
\hline size & $\begin{array}{l}\text { size of firm } i \text { in year } t \text { calculated as the natural logarithm of the firm's total } \\
\text { assets }\end{array}$ \\
\hline distress & $\begin{array}{l}\text { an indicator variable equal to } 1 \text { if firm } i \text { exhibits negative equity in year } \mathrm{t} \text {, and } 0 \\
\text { otherwise }\end{array}$ \\
\hline tangibility & tangible assets / total assets \\
\hline
\end{tabular}




\begin{tabular}{|c|c|}
\hline Variable & Definition of variables \\
\hline TA & $\begin{array}{l}\text { tax avoidance, } \mathrm{TA}=\text { tax rate }- \text { etr, where etr }- \text { effective tax rate, etr }= \\
\text { taxation/gross_profit. I replace etr }=0 \text { if etr }<0 \text { and etr }=1 \text { if etr }>1 . T A \text { is } \\
\text { truncated to the range }\langle 0,0.19\rangle \text {. }\end{array}$ \\
\hline roa & return on assets, roa $=$ gross profit $/$ total assets \\
\hline growth ( $\Delta$ sales $)$ & $\begin{array}{l}\text { sales of firm } i \text { in year } t / \text { total assets - sales of firm } i \text { in year } t-1 / \text { total assets in } \\
\text { year } t-1\end{array}$ \\
\hline borrower & $\begin{array}{l}\text { dummy variable of firm } i \text { in year } t \text { equal to } 1 \text { if a company borrowed a bank } \\
\text { loan and has at least one positive value among: long-term bank loans, short- } \\
\text { term bank loans }\end{array}$ \\
\hline
\end{tabular}

Table 3. Descriptive statistics

\begin{tabular}{lccccccc}
\hline \multicolumn{1}{c}{ Variable } & Number of observations & $\begin{array}{c}\text { 10th } \\
\text { Percentile }\end{array}$ & $\begin{array}{c}\text { 25th } \\
\text { Percentile }\end{array}$ & Mean & Median & 75th Percentile & 90th Percentile \\
\hline permbtd & 179,395 & 0.0015 & 0.0068 & 0.1090 & 0.0246 & 0.0851 & 0.2516 \\
btd & 162,496 & 0.0021 & 0.0090 & 0.0755 & 0.0315 & 0.0919 & 0.2080 \\
accruals & 179,395 & -0.2889 & -0.1234 & -0.0455 & -0.0278 & 0.0514 & 0.1966 \\
one_book & 179,395 & 0 & 1 & 0.7619 & 1 & 1 & 1 \\
two-book & 179,395 & 0 & 0 & 0.2381 & 0 & 0 & 1 \\
gaap_first & 179,395 & 0.0000 & 0.0000 & 0.0145 & 0.0000 & 0.0024 & 0.0330 \\
tax_first & 179,395 & 0.0012 & 0.0217 & 0.0966 & 0.0560 & 0.1171 & 0.2244 \\
leverage & 179,395 & 0.0647 & 0.2458 & 3.4419 & 0.8461 & 2.2795 & 6.2747 \\
non_bank leverage & 162,496 & 0.0022 & 0.0763 & 0.1601 & 0.2248 & 0.4435 & 0.6676 \\
bank_loan & 162,496 & 0 & 0 & 0.1095 & 0 & 0.1491 & 0.3680 \\
loss & 179,395 & 0 & 0 & 0.2949 & 0 & 1 & 1 \\
size & 179,395 & 11.6307 & 13.0400 & 14.5833 & 14.5991 & 16.1344 & 17.4508 \\
distress & 179,395 & 0 & 0 & 0.1128 & 0 & 0 & 1 \\
tangibility & 179,395 & 0.0000 & 0.0088 & 0.2545 & 0.1457 & 0.4357 & 0.7063 \\
tax avoidance (TA) & 179,395 & 0 & 0 & 0.0811 & 0.0129 & 0.1900 & 0.1900 \\
roa & 179,395 & -0.1679 & -0.0134 & 0.0349 & 0.0409 & 0.1446 & 0.3000 \\
growth $(\Delta$ sales) & 139,845 & -0.8093 & -0.2548 & -0.0537 & 0.0000 & 0.1646 & 0.6347 \\
borrower & 162,496 & 0 & 0 & 0.4732 & 0 & 1 & 1 \\
\hline
\end{tabular}

Table 4. Pairwise correlations

\begin{tabular}{|c|c|c|c|c|c|c|c|c|c|}
\hline $\begin{array}{c}\text { total } \\
\text { sample }\end{array}$ & accruals & $\begin{array}{c}\text { one_boo } \\
\mathbf{k}\end{array}$ & $\begin{array}{c}\text { gaap_fir } \\
\text { st }\end{array}$ & tax_first & $\begin{array}{c}\text { non_ban } \\
\mathbf{k} \\
\text { leverage }\end{array}$ & $\begin{array}{c}\text { bank_lo } \\
\text { an }\end{array}$ & size & loss & distress \\
\hline accruals & $\begin{array}{c}1.0000 \\
0.0109 * *\end{array}$ & & & & & & & & \\
\hline one_book & $\begin{array}{l}* \\
-\end{array}$ & $\begin{array}{c}1.0000 \\
-\end{array}$ & & & & & & & \\
\hline gaap_first & $\begin{array}{c}0.0108 * * \\
* \\
-\end{array}$ & $\begin{array}{c}0.3030 * * \\
* \\
-\end{array}$ & 1.0000 & & & & & & \\
\hline tax_first & $\begin{array}{c}0.1426 * * \\
*\end{array}$ & $\begin{array}{c}0.0684 * * \\
*\end{array}$ & $\begin{array}{c}0.0602^{* *} \\
*\end{array}$ & 1.0000 & & & & & \\
\hline $\begin{array}{l}\text { non_bank } \\
\text { leverage }\end{array}$ & $\begin{array}{c}0.0633 * * \\
*\end{array}$ & $\begin{array}{c}- \\
0.0731 * * \\
*\end{array}$ & $\begin{array}{c}0.0132 * * \\
*\end{array}$ & $\begin{array}{c}- \\
0.0126 * * \\
*\end{array}$ & 1.0000 & & & & \\
\hline
\end{tabular}


Private SME accounting in Poland. Does bank lending influence their accounting and financial reporting practice?

\begin{tabular}{|c|c|c|c|c|c|c|c|c|c|}
\hline $\begin{array}{c}\text { total } \\
\text { sample }\end{array}$ & accruals & $\underset{\mathbf{k}}{\text { one_boo }}$ & $\begin{array}{c}\text { gaap_fir } \\
\text { st }\end{array}$ & tax_first & $\begin{array}{c}\text { non_ban } \\
\mathbf{k} \\
\text { leverage }\end{array}$ & $\begin{array}{c}\text { bank_lo } \\
\text { an }\end{array}$ & size & loss & distress \\
\hline $\begin{array}{l}\text { bank_loa } \\
\mathrm{n}\end{array}$ & $\begin{array}{c}0.0315^{* *} \\
*\end{array}$ & $\begin{array}{c}- \\
0.0053^{* *} \\
-\end{array}$ & $\begin{array}{c}- \\
0.0739 * * \\
*\end{array}$ & $\begin{array}{c}0.0119 * * \\
*\end{array}$ & $\begin{array}{c}- \\
0.3111^{* *} \\
*\end{array}$ & 1.0000 & & & \\
\hline size & $\begin{array}{c}0.0137 * * \\
* \\
-\end{array}$ & $\begin{array}{c}0.5299 * * \\
*\end{array}$ & $\begin{array}{c}0.2471 * * \\
* \\
-\end{array}$ & $\begin{array}{c}0.0929 * * \\
*\end{array}$ & $\begin{array}{c}0.1873 * * \\
* \\
-\end{array}$ & $\begin{array}{c}0.0106^{* * *} \\
*\end{array}$ & $\begin{array}{c}1.0000 \\
-\end{array}$ & & \\
\hline loss & $\begin{array}{c}0.1842 * * \\
* \\
-\end{array}$ & $\begin{array}{c}0.0956^{* *} \\
*\end{array}$ & $\begin{array}{c}0.0088^{* *} \\
*\end{array}$ & 0.0004 & $\begin{array}{c}0.2423^{* *} \\
* \\
-\end{array}$ & $\begin{array}{c}0.0854 * * \\
*\end{array}$ & $\begin{array}{c}0.2257^{* *} \\
* \\
-\end{array}$ & 1.0000 & \\
\hline distress & $\begin{array}{c}0.1046^{* *} \\
* \\
-\end{array}$ & $\begin{array}{c}0.0592 * * \\
* \\
-\end{array}$ & $0.0042 *$ & $\begin{array}{c}0.0245 * * \\
*\end{array}$ & $\begin{array}{c}0.8705^{* *} \\
* \\
-\end{array}$ & $\begin{array}{c}0.2012^{* *} \\
*\end{array}$ & $\begin{array}{c}0.1144^{* *} \\
*\end{array}$ & $\begin{array}{c}0.2827 * * \\
*\end{array}$ & 1.0000 \\
\hline $\operatorname{tang}$ & $\begin{array}{c}0.1102 * * \\
* \\
-\end{array}$ & $\begin{array}{c}0.1267 * * \\
*\end{array}$ & $\begin{array}{c}-0.0007 \\
-\end{array}$ & $\begin{array}{c}0.1501 * * \\
* \\
-\end{array}$ & $\begin{array}{c}0.0452 * * \\
* \\
-\end{array}$ & $\begin{array}{c}0.2820 * * \\
*\end{array}$ & $\begin{array}{c}0.1369 * * \\
* \\
-\end{array}$ & $\begin{array}{c}0.0322 * * \\
*\end{array}$ & $\begin{array}{c}0.0323 * * \\
*\end{array}$ \\
\hline TA & $\begin{array}{c}0.0554 * * \\
*\end{array}$ & $\begin{array}{c}0.1080^{* *} \\
* \\
-\end{array}$ & $\begin{array}{c}0.0535^{* *} \\
* \\
-\end{array}$ & $\begin{array}{c}0.0282 * * \\
* \\
-\end{array}$ & $\begin{array}{c}0.1895^{* *} \\
*\end{array}$ & $\begin{array}{c}0.0533^{* *} * \\
* \\
-\end{array}$ & $\begin{array}{c}0.1762^{* *} \\
*\end{array}$ & $\begin{array}{c}0.4271 * * \\
* \\
-\end{array}$ & $\begin{array}{c}0.1939 * * \\
*\end{array}$ \\
\hline roa & $\begin{array}{c}0.2600 * * \\
*\end{array}$ & $\begin{array}{c}0.0210^{* *} \\
*\end{array}$ & $\begin{array}{c}0.0073 * * \\
*\end{array}$ & $\begin{array}{c}0.0589 * * \\
*\end{array}$ & $\begin{array}{c}0.1919 * * \\
*\end{array}$ & $\begin{array}{c}0.1573 * * \\
*\end{array}$ & $\begin{array}{c}0.1198^{* *} \\
*\end{array}$ & $\begin{array}{c}0.6305^{* *} \\
*\end{array}$ & $\begin{array}{l}0.2437^{* *} * \\
*\end{array}$ \\
\hline $\begin{array}{l}\text { growth } \\
\text { ( } \triangle \text { sales })\end{array}$ & 0.0044 & $\begin{array}{l}- \\
0.0173^{* *} \\
*\end{array}$ & $\begin{array}{l}0.0253^{* * *} \\
*\end{array}$ & $\begin{array}{l}0.0485^{* *} \\
*\end{array}$ & $\begin{array}{l}- \\
0.0264 * * \\
*\end{array}$ & $\begin{array}{l}- \\
0.0096 * * \\
*\end{array}$ & $\begin{array}{l}0.0561 * * \\
*\end{array}$ & $\begin{array}{l}0.0107^{*} * \\
*\end{array}$ & $\begin{array}{c}0.0211 * * \\
*\end{array}$ \\
\hline $\begin{array}{c}\text { total } \\
\text { sample }\end{array}$ & $\begin{array}{c}\text { tangibilit } \\
\mathrm{y}\end{array}$ & TA & roa & growth & & & & & \\
\hline $\operatorname{tang}$ & $\begin{array}{c}1.0000 \\
0.0121^{* *}\end{array}$ & & & & & & & & \\
\hline TA & * & $\begin{array}{r}1.0000 \\
-\quad\end{array}$ & & & & & & & \\
\hline roa & $\begin{array}{l}0.1343 * * \\
*\end{array}$ & $\begin{array}{l}0.2481 * * \\
*\end{array}$ & 1.0000 & & & & & & \\
\hline $\begin{array}{l}\text { growth } \\
\text { ( } \triangle \text { sales) }\end{array}$ & $\begin{array}{c}0.0395 * * \\
*\end{array}$ & -0.0002 & $\begin{array}{c}- \\
0.0142 * * \\
*\end{array}$ & 1.0000 & & & & & \\
\hline
\end{tabular}

Significant at $1 \%-* * *, 5 \%-* *, 10 \%-*$

Tax avoidance reaches $8 \mathrm{pp}$. compared to the $19 \%$ nominal tax rate and more than $25 \%$ of firms do not pay any income tax at all (TA equals 0.19 for those firms). The effective tax rate in more than $25 \%$ of firms exceeds the nominal tax rate, which is a result of non-tax-deductible expenses. Permanent differences (permbtd) are $40 \%$ higher on average than total permanent and temporary differences $(b t d)$. This indicates a significant share of negative temporary differences resulting from taxdeductible costs being deferred. Borrowers represent $47 \%$ of the research sample. On average, $11 \%$ of assets are financed by bank loans and $16 \%$ by other types of credit. Although the average leverage indicates that the share of debt in the capital structure is 3.5 times higher than that of equity, little debt is used (no more than $27 \%$ of assets). This may be partly due to financial losses that reduced the equity level. In the research sample losses were recorded by $29.5 \%$ of companies, and $11.3 \%$ showed a negative equity value (due to the share capital being outbalanced by accumulated losses of the current year and previous years). Financial losses additionally increased 
book-tax differences. The average profitability of assets equals 3.5\%, while more than half of firms had experienced a decrease in revenue from sales in year $t$ against year $t-1$. Fixed assets - a potential bank loan collateral - accounted for $25 \%$ of total assets on average and $14.6 \%$ in the median value. The correlation matrix indicates that larger firms are less likely to avoid taxation, incur fewer financial losses and have one-book accounting less often, while showing a positive correlation with advanced accounting tools (gaap-first) to a greater degree than with tax regulations (tax_first) (Table 4). Furthermore, larger companies use more bank borrowing and non-bank borrowing. Financial losses are positively correlated with bank borrowing and negatively with non-bank external funding. A higher share of fixed assets used as debt collateral is positively correlated with bank loans, and negatively correlated using one-book accounting systems. Profitable firms have higher accruals and are less likely to avoid taxations (a negative correlation). There is a high correlation between the distress variable and non-bank leverage.

\section{Results}

The main results of the models estimation for both dependent variables: permbtd and $b t d$, are summarised in Table 5. The main difference between these regressions identified by the results is that one-book companies have lower book-tax conformity when I consider permanent differences (permbtd - this is the measurement proposed by Watrin et al. (2014)), but higher book-tax conformity when I consider permanent and temporary differences together (btd - the measure proposed by Tang (2015)). For two-book borrowers this relationship is insignificant, while weaker (lower coefficients) for the $b t d$ variable, for one-book borrowers as opposed to nonborrowers. For the total sample (both profitable and unprofitable firms included) the rest of the findings are the same in the scope of the sign and significance of the coefficients for both variants of the dependent variable, except for the size variable. A higher share of bank loans in the capital structure, in relation to total assets, increase book-tax conformity. This indicates that there is no basis for rejecting hypothesis H1. These results confirm lower lenders demand for financial information relevant to shareholders and investors. Higher earnings informativeness is important to estimate future cash flow and evaluate the company's market value, whereas creditors are more interested in the company's liquidation value and its capability of paying its liabilities rather than the future growth in company value since they do not participate in any future profits. This could be explained by the asymmetry between the payments of investor and lender shares in profits earned on debt-financed investments (Black \& Scholes, 1973). In the opinion of Blaylock et al. (2016), this asymmetrical share in the future profits of borrowers suggests that increasing book-tax conformity may potentially shift a company's capital structure towards the greater use of debt-based financing. However, these findings also signal that higher book-tax conformity results in a decrease in the borrower's earnings informativeness. Because higher non-bank borrowings (non-bank leverage) are also 
negatively associated with the book-tax conformity, it appears that bank-lender expectations towards borrower's earnings informativeness do not differ from other creditors. Therefore, I decided to estimate the models separately for profitable and unprofitable firms to locate any disparity (Tables 6-7). The use of the accrual method increases book-tax conformity more in the case of borrowers. While making use of more advanced accounting practices and adhering to the prudence principle and the matching principle (the gaap_first variable) decreases book-tax conformity further in the case of borrowers. This allows lenders to learn more about borrower creditworthiness and ability to repay the bank loan thanks to more informative earnings. Recognizing and recording business operations in accordance with tax regulations (the tax_first variable) also decreases book-tax conformity. However, the coefficients at this tax_first variable are lower in the case of borrowers, irrespective of the model. This indicates that borrowers recognize business operations less according to tax law in contrast to non-borrowers. This confirms the hypothesis $\mathrm{H} 2$.

Tax avoidance (TA) leads to decreased book-tax conformity, less so in the case of borrowers, in accordance with the hypothesis H3. Higher book-tax conformity is accompanied by less tax avoidance (Tang, 2015, Chan et al., 2010, Atwood et al., 2012). Politicians and regulators (legislators) in the USA are calling for an increase in book-tax conformity, in order to reduce aggressive tax optimisation practices adopted by businesses (Blaylock et al., 2016).

Table 5. Results of the panel analysis of determinants of book-tax conformity measured with the use of permanent book-tax differences (permbtd) and temporary $\&$ permanent book-tax differential (btd)

\begin{tabular}{|c|c|c|c|}
\hline & & $\begin{array}{c}\text { btd } \\
\text { total sample }\end{array}$ & $\begin{array}{c}\text { permbtd } \\
\text { total sample }\end{array}$ \\
\hline \multirow[t]{2}{*}{ accruals $\mathrm{x}$ borrower } & 0 & $\begin{array}{c}-0.0097 * * * \\
(0.0017)\end{array}$ & $\begin{array}{c}-0.0110 * * * \\
(0.0016)\end{array}$ \\
\hline & 1 & $\begin{array}{c}-0.0328 * * * \\
(0.0022)\end{array}$ & $\begin{array}{c}-0.0318 * * * \\
(0.0020)\end{array}$ \\
\hline \multirow[t]{2}{*}{ gaap_first x borrower } & 0 & $\begin{array}{c}0.4050 * * * \\
(0.0151)\end{array}$ & $\begin{array}{c}0.2031 * * * \\
(0.0137)\end{array}$ \\
\hline & 1 & $\begin{array}{c}0.4734 * * * \\
(0.0175)\end{array}$ & $\begin{array}{c}0.2529 * * * \\
(0.0159)\end{array}$ \\
\hline \multirow[t]{2}{*}{ tax_first $\mathrm{x}$ borrower } & 0 & $\begin{array}{c}0.0406^{* * * *} \\
(0.0050)\end{array}$ & $\begin{array}{c}0.0298 * * * \\
(0.0046)\end{array}$ \\
\hline & 1 & $\begin{array}{c}0.0200 * * * \\
(0.0052)\end{array}$ & $\begin{array}{c}0.0152 * * * \\
(0.0046)\end{array}$ \\
\hline \multirow[t]{2}{*}{ non-bank leverage $\mathrm{x}$ borrower } & 0 & $\begin{array}{c}-0.0226 * * * \\
(0.0011)\end{array}$ & $\begin{array}{c}-0.0195 * * * \\
(0.0010)\end{array}$ \\
\hline & 1 & $\begin{array}{c}\mathbf{- 0 . 0 3 0 8} * * * \\
(0.0010)\end{array}$ & $\begin{array}{c}-\mathbf{- 0 . 0 2 8 6} * * * \\
(0.0009)\end{array}$ \\
\hline bank loan & & $\begin{array}{c}-\mathbf{- 0 . 0 2 9 6 * * * *} \\
(0.0031)\end{array}$ & $\begin{array}{c}-\mathbf{0 . 0 2 1 9} * * * \\
(0.0028)\end{array}$ \\
\hline one_book $\mathrm{x}$ borrower & 01 & -0.0009 & 0.0009 \\
\hline
\end{tabular}




\begin{tabular}{|c|c|c|c|}
\hline & & $\begin{array}{c}\text { btd } \\
\text { total sample }\end{array}$ & $\begin{array}{c}\text { permbtd } \\
\text { total sample }\end{array}$ \\
\hline & & $(0.0017)$ & $(0.0016)$ \\
\hline & 10 & $-0.0343 * * *$ & $0.0113 * * *$ \\
\hline & & $(0.0016)$ & $(0.0014)$ \\
\hline & 11 & $-0.0268 * * *$ & $0.0113 * * *$ \\
\hline & & $(0.0019)$ & $(0.0017)$ \\
\hline \multirow[t]{4}{*}{ TA (tax avoidance) $\mathrm{x}$ borrower } & 0 & $0.0358 * * *$ & $0.0469 * * *$ \\
\hline & & $(0.0024)$ & $(0.0023)$ \\
\hline & 1 & $0.0305 * * *$ & $0.0350 * * *$ \\
\hline & & $(0.0022)$ & $(0.0020)$ \\
\hline \multirow[t]{2}{*}{ size } & & -0.0006 & $-0.0012 * * *$ \\
\hline & & $(0.0004)$ & $(0.0003)$ \\
\hline \multirow[t]{2}{*}{ tangibility } & & $-0.0206 * * *$ & $-0.0152 * * *$ \\
\hline & & $(0.0021)$ & $(0.0019)$ \\
\hline \multirow[t]{2}{*}{ roa } & & $-0.1585 * * *$ & $-0.1258 * * *$ \\
\hline & & $(0.0021)$ & $(0.0019)$ \\
\hline \multirow[t]{2}{*}{ growth ( $\triangle$ sales) } & & $0.0021 * * *$ & $0.0020 * * *$ \\
\hline & & $(0.0002)$ & $(0.0002)$ \\
\hline \multirow[t]{2}{*}{ _cons } & & $0.1035 * * *$ & $0.0601 * * *$ \\
\hline & & $(0.0068)$ & $(0.0057)$ \\
\hline Number of observations & & 114,741 & 114,741 \\
\hline Number of groups & & 23,459 & 23,459 \\
\hline $\mathrm{R}^{2}$ within & & 0.1973 & 0.2021 \\
\hline
\end{tabular}

Significant at $1 \%$ - ***, 5\% - **, $10 \%$ - *, standard errors in brackets below the estimated coefficients

Control variables are significant in all models and show the same direction of influence, no matter if deferred tax is recorded in the books or not: negative for size,

roa and tangibility, and positive for growth ( $\Delta$ sales). Larger companies (size) show higher book-tax conformity than smaller ones. As the subject literature shows, there may be a correlation between the higher book-tax conformity of larger companies and lower or less frequent tax planning, and the lower demand for information relevant to owners or investors interested in the future growth of the company's value. The higher share of fixed assets in total assets (tangibility) reflects a greater consistency in accounting and tax regulation, including those applicable to depreciation and to historical cost valuation. This increases book-tax conformity. Increase in return on assets ( $r o a)$ is associated with the higher book-tax conformity.

Companies that experience a sales boost (growth ( $\Delta$ sales)) show less book-tax conformity, which may be due to earnings management or differences in the time of revenue and cost recognition for book-related and tax-related purposes. The lower book-tax conformity that accompanies sales growth may also follow when taxable income is reduced by tax losses of previous years, or when other tax optimization measures are taken in order to reduce the tax burden despite growing sales. 
The results of the models estimation for both dependent variables: permbtd and btd for unprofitable SMEs (with financial losses), are summarised in Table 6. The onebook unprofitable non-borrowers have lower book-tax conformity for the measurement proposed by Watrin et al. (2014) (permbtd), but higher book-tax conformity for the measure proposed by Tang (2015) (btd), whereas two-book borrowers have higher book-tax conformity for the btd dependent variable. This allows confirmation for the hypothesis $\mathbf{H 1}$ for unprofitable two-book borrowers (with financial losses).

Table 6. Results of the panel analysis of determinants of book-tax conformity measured with the use of permanent book-tax differences (permbtd) and temporary $\&$ permanent book-tax differential (btd) for private firms with financial losses

\begin{tabular}{|c|c|c|c|}
\hline & & btd & permbtd \\
\hline \multirow[t]{4}{*}{ accruals $\mathrm{x}$ borrower } & 0 & $0.0063 *$ & -0.0032 \\
\hline & & $(0.0034)$ & $(0.0029)$ \\
\hline & 1 & -0.0051 & $-0.0059 *$ \\
\hline & & $(0.0044)$ & $(0.0037)$ \\
\hline \multirow[t]{4}{*}{ gaap_first x borrower } & 0 & $0.1361 * * *$ & -0.0275 \\
\hline & & $(0.0326)$ & $(0.0248)$ \\
\hline & 1 & $0.0768 * *$ & 0.0196 \\
\hline & & $(0.0311)$ & $(0.0246)$ \\
\hline \multirow[t]{4}{*}{ tax_first $\mathrm{x}$ borrower } & 0 & 0.0014 & $0.0220 * *$ \\
\hline & & $(0.0104)$ & $(0.0076)$ \\
\hline & 1 & -0.0031 & -0.0023 \\
\hline & & $(0.0110)$ & $(0.0080)$ \\
\hline \multirow[t]{4}{*}{ non-bank leverage $\mathrm{x}$ borrower } & 0 & $-0.0028 *$ & -0.0002 \\
\hline & & $(0.0015)$ & $(0.0011)$ \\
\hline & 1 & $-0.0042 * * *$ & $-0.0038 * * *$ \\
\hline & & $(0.0014)$ & $(0.0010)$ \\
\hline \multirow[t]{2}{*}{ bank loan } & & -0.0015 & -0.0007 \\
\hline & & $(0.0055)$ & $(0.0039)$ \\
\hline \multirow[t]{6}{*}{ one_book x borrower } & 01 & $-0.0184 * *$ & -0.0093 \\
\hline & & $(0.0083)$ & $(0.0065)$ \\
\hline & 10 & $-0.0648 * * *$ & $0.0163^{* * * *}$ \\
\hline & & $(0.0035)$ & $(0.0023)$ \\
\hline & 11 & $-0.0737 * * *$ & 0.0083 \\
\hline & & $(0.0082)$ & $(0.0062)$ \\
\hline \multirow[t]{4}{*}{ TA (tax avoidance) $\mathrm{x}$ borrower } & 0 & $-0.2410 * * *$ & $-0.3121 * * *$ \\
\hline & & $(0.0273)$ & $(0.0203)$ \\
\hline & 1 & $-0.1901 * * *$ & $-0.2700 * * *$ \\
\hline & & $(0.0292)$ & $(0.0250)$ \\
\hline \multirow[t]{2}{*}{ size } & & $0.0049 * * *$ & $0.0037 * * *$ \\
\hline & & $(0.0005)$ & $(0.0003)$ \\
\hline \multirow[t]{2}{*}{ tangibility } & & -0.0029 & -0.00003 \\
\hline & & $(0.0039)$ & $(0.0026)$ \\
\hline \multirow[t]{2}{*}{ roa } & & $-0.9618 * * *$ & $-0.9478 * * *$ \\
\hline & & $(0.0057)$ & $(0.0046)$ \\
\hline
\end{tabular}




\begin{tabular}{lcc}
\hline & & \\
growth $(\triangle$ sales $)$ & btd & permbtd \\
& 0.0004 & 0.0001 \\
_cons & $(0.0003)$ & $(0.0001)$ \\
& $0.0526^{* * *}$ & 0.0018 \\
\hline Number of observations & $(0.0083)$ & $(0.0018)$ \\
Number of groups & 18,240 & 18,240 \\
$\mathrm{R}^{2}$ within & 8,956 & 8,956 \\
\hline
\end{tabular}

Significant at $1 \%-* * *, 5 \%-* *, 10 \%-*$, standard errors in brackets below the estimated coefficients

The higher book-tax conformity of borrowers with poor financial standing results in the decrease in their earnings informativeness for lenders. However, the impact of separate bank loan variable is insignificant in these models for unprofitable firms. Therefore, the conclusions for the hypothesis $\mathbf{H 1}$ are not clear in the case of onebook and total unprofitable borrowers. A higher share of non-bank borrowings in the capital structure (non-bank leverage) increases book-tax conformity in the case of borrowers.

It is worth noting that companies with losses are likely to not pay any income tax and therefore often show zero taxable income and non-zero (negative) accounting income. As a consequence, their book-tax differences are equal to the absolute value of their accounting income. It could be expected that limited liability companies and joint-stock companies facing the risk of bankruptcy due to equity decrease or a negative equity value show higher differences between their pre-tax income and taxable income. The lower book-tax conformity may be due to the financial losses recorded in the current year or due to the deduction of tax losses incurred in previous years. In Poland, tax losses may be deducted from taxable income over 5 years and no more than $50 \%$ of a given year's annual tax loss.

The use of the accrual method increases book-tax conformity in a degree of permanent book-tax differences in the case of borrowers, while decreasing nonborrowers book-tax conformity for total book-tax differential $(b t d)$. Whereas making use of more advanced accounting practices (the gaap_first variable) decreases booktax conformity less in the case of borrowers than non-borrowers (for the btd dependent variable). Recognizing and recording business operations in accordance with tax regulations (the tax_first variable) is insignificant for unprofitable borrowers, irrespective of the model. While for unprofitable non-borrowers this factor decreases book-tax conformity in an extent of the permanent book-tax differential. These signal that unprofitable borrowers recognize business operations more according to accounting standards as the impact of tax law is insignificant. These only allow the partial confirmation of hypothesis H2. Tax avoidance (TA) leads to an increase in book-tax conformity, less so in the case of unprofitable borrowers than non-borrowers with financial losses, in accordance with hypothesis $\mathrm{H} 3$. Out of control variables only size and roa are significant in all models. The size 
variable shows the opposite direction of influence than for the total sample. Larger unprofitable firms show lower book-tax conformity than smaller ones with poor financial standing.

The results of the models estimation for profitable SMEs for both dependent variables: permbtd and $b t d$, are summarized in Table 7 . The main difference between these regression findings and models estimated for the total sample (Table 5) constitute the opposite impact of the accruals and roa. The profitable one-book borrowers have lower book-tax conformity when I consider permanent differences (permbtd), but higher book-tax conformity when I take into account the total booktax differences together $(b t d)$ apart from two-book profitable borrowers.

The non-bank borrowings share in the capital structure (non-bank leverage) increases book-tax conformity, whereas a higher share of bank loans is correlated with higher book-tax conformity solely for the $b t d$ dependent variable. This indicates that there is no basis for rejecting hypothesis $\mathrm{H} 1$ for the total temporary and permanent book-tax differences (btd) of profitable borrowers. These results show lower lenders demand for earnings informativeness as previous studies have proved that an increase in book-tax conformity results in the reduced informativeness of earnings (Hanlon et al., 2008; Atwood et al., 2010). The use of the accrual method decreases solely a nonborrower's book-tax conformity. Making use of more advanced accounting practices and adhering to the prudence principle and the matching principle (the gaap_first variable) decreases book-tax conformity more in the case of borrowers when consider the btd variable. This allows lenders to learn more about borrower creditworthiness and the ability to repay the bank loan thanks to more informative earnings for the btd measure of book-tax conformity. The opposite conclusions are given for the permbtd dependent variable. Recognizing business operations in accordance with tax regulations (the tax_first variable) also decreases book-tax conformity, however, the coefficients at this tax_first variable are lower in the case of borrowers, irrespective of the model. This indicates that borrowers recognize business operations less according to tax law contrary to nonborrowers. This confirms the hypothesis $\mathrm{H} 2$. However, the findings for the permbtd variable are weaker than for the alternative measure proposed by Tang (2015) (btd). In the case of profitable SMEs, tax avoidance (TA) leads to a decrease in book-tax conformity, less so in the case of borrowers, in accordance with the hypothesis H3.

Control variables are significant in all models except for the size variable. The firm size variable shows the negative influence for the permbtd variable, whereas is insignificant for the btd variable. Larger companies (size) show higher book-tax conformity than smaller ones in the case of permanent book-tax differences. The roa variable indicates the opposite direction of influence than in models for the total sample. More profitable companies have a lower book-tax conformity and provide lenders and non-bank creditors with more informative earnings. The outcomes for the tangibility and growth variable are in line with findings for the total sample that consists of profitable and unprofitable firms. 
Table 7. Results of the panel analysis of determinants of book-tax

\begin{tabular}{|c|c|c|c|}
\hline & & $\begin{array}{c}\text { btd } \\
\operatorname{loss}=0\end{array}$ & $\begin{array}{c}\text { permbtd } \\
\operatorname{los} s=0\end{array}$ \\
\hline \multirow[t]{4}{*}{ accruals x borrower } & 0 & $0.0030 * *$ & 0.0009 \\
\hline & & $(0.0016)$ & $(0.0014)$ \\
\hline & 1 & 0.0004 & 0.0019 \\
\hline & & $(0.0020)$ & $(0.0017)$ \\
\hline \multirow[t]{4}{*}{ gaap_first x borrower } & 0 & $0.4047 * * *$ & $0.1921 * * *$ \\
\hline & & $(0.0135)$ & $(0.0110)$ \\
\hline & 1 & $0.4230 * * *$ & $0.1895 * * *$ \\
\hline & & $(0.0167)$ & $(0.0137)$ \\
\hline \multirow[t]{4}{*}{ tax_first $\mathrm{x}$ borrower } & 0 & $0.0482 * * *$ & $0.0217 * * *$ \\
\hline & & $(0.0045)$ & $(0.0038)$ \\
\hline & 1 & $0.0262 * * *$ & $0.0158 * * *$ \\
\hline & & $(0.0046)$ & $(0.0038)$ \\
\hline \multirow[t]{4}{*}{ non-bank leverage $\mathrm{x}$ borrower } & 0 & $-0.0049 * * *$ & $-0.0022 *$ \\
\hline & & $(0.0015)$ & $(0.0012)$ \\
\hline & 1 & $-0.0077 * * *$ & $-0.0056 * * *$ \\
\hline & & $(0.0015)$ & $(0.0013)$ \\
\hline \multirow[t]{2}{*}{ bank loan } & & $-0.0059 * *$ & 0.00004 \\
\hline & & $(0.0030)$ & $(0.0024)$ \\
\hline \multirow[t]{6}{*}{ one_book x borrower } & 01 & $0.0033 * *$ & $0.0024 *$ \\
\hline & & $(0.0015)$ & $(0.0013)$ \\
\hline & 10 & $-0.0303 * * *$ & $0.0024 * *$ \\
\hline & & $(0.0013)$ & $(0.0012)$ \\
\hline & 11 & $-0.0218 * * *$ & $0.0031 * *$ \\
\hline & & $(0.0017)$ & $(0.0015)$ \\
\hline \multirow[t]{4}{*}{ TA (tax avoidance) $x$ borrower } & 0 & $0.3025^{* * *}$ & $0.4206 * * *$ \\
\hline & & $(0.0025)$ & $(0.0048)$ \\
\hline & 1 & $0.1734 * * *$ & $0.2695 * * *$ \\
\hline & & $(0.0054)$ & $(0.0045)$ \\
\hline \multirow[t]{2}{*}{ size } & & -0.0006 & $-0.0025 * * *$ \\
\hline & & $(0.0004)$ & $(0.0003)$ \\
\hline \multirow[t]{2}{*}{ tangibility } & & $-0.0080 * * *$ & $-0.0045^{* *}$ \\
\hline & & $(0.0019)$ & $(0.0016)$ \\
\hline \multirow[t]{2}{*}{ roa } & & $0.1319 * * *$ & $0.1489 * * *$ \\
\hline & & $(0.0022)$ & $(0.0018)$ \\
\hline \multirow[t]{2}{*}{ growth ( $\triangle$ sales) } & & $0.0008 * * *$ & $0.0006^{* * *}$ \\
\hline & & $(0.0002)$ & $(0.0002)$ \\
\hline \multirow{2}{*}{ _cons } & & $0.0479 * * *$ & $0.0354 * * *$ \\
\hline & & $(0.0062)$ & $(0.0045)$ \\
\hline \multicolumn{2}{|l|}{ Number of observations } & 83,122 & 83,122 \\
\hline & 20,309 & 20,309 \\
\hline \multicolumn{2}{|l|}{$\begin{array}{l}\text { Number of groups } \\
R^{2} \text { within }\end{array}$} & 0.1223 & 0.2083 \\
\hline
\end{tabular}


The higher share of fixed assets in total assets (tangibility) reflects a greater consistency in accounting and tax regulation, including those applicable to depreciation and to historical cost valuation (a fair value is not permitted for tangible assets under local GAAP). Companies that experience a sales boost (growth ( $\Delta$ sales)) show less book-tax conformity, which may be due to earnings management or differences in the time of revenue and cost recognition for book-related and taxrelated purposes.

Table 8 presents a comparison of accounting policy applied by borrowers and nonborrowers which confirms that more borrowers (22.5\%) use items of advanced accounting policy included in gaap_first than non-borrowers (18\%). However, total exceptional items (calculated as a difference between financial revenues from revaluation of financial investments and the sum of financial costs of revaluation of financial investments and other operating costs of the revaluation of non-financial assets) are negative for all borrowers contrary to non-borrowers. This confirms that borrowers applied more conservative accounting than non-borrowers. More borrowers recognize the short-term provisions and negative effects of a revaluation of non-financial assets. Although more borrowers recognize items of accounting policy included in the tax_first variable, the $99^{\text {th }}$ percentile of their relative value is much lower than in non-borrowers, except for long-term other accruals.

Table 8. Comparison of accounting policy applied by borrowers and non-borrowers

\begin{tabular}{|c|c|c|c|c|c|}
\hline & & $\mathbf{N}$ & $\%$ & $10 \mathrm{P}$ & 99P \\
\hline \multirow{5}{*}{ total exceptional items } & non- & 1796 & 18.06 & - & 0.000 \\
\hline & borrower & 2 & & 0.0037 & 7 \\
\hline & & 2229 & 22.45 & - & \\
\hline & borrower & 1 & $\%$ & 0.0056 & 0 \\
\hline & & $\mathbf{N}$ & $\%$ & 90P & 99P \\
\hline \multirow{4}{*}{$\begin{array}{l}\text { positive effects of revaluation of financial investments (included in financial } \\
\text { revenues) }\end{array}$} & non- & & & & 0.017 \\
\hline & borrower & 2004 & $2.02 \%$ & 0 & \\
\hline & & 1870 & 18007 & & 0.024 \\
\hline & Domower & 1019 & $1.09 \%$ & 0 & \\
\hline \multirow{4}{*}{ items of advanced accounting policy included in gaap_first } & & $\mathbf{N}$ & $\%$ & 90P & 99P \\
\hline & non- & 1584 & & & 0.413 \\
\hline & borrower & 7 & $16 \%$ & 0.0102 & 6 \\
\hline & & 2046 & & & 0.255 \\
\hline \multirow[t]{3}{*}{ revaluation of non-financial assets (included in other operating costs) } & borrower & 5 & $21 \%$ & 0.0123 & 1 \\
\hline & non- & & & & 0.032 \\
\hline & borrower & 2596 & $2.61 \%$ & 0 & 3 \\
\hline \multirow{3}{*}{$\begin{array}{l}\text { negative effects of revaluation of financial investments (included in financial } \\
\text { costs) }\end{array}$} & & & & & 0.085 \\
\hline & borrower & 3089 & $3.11 \%$ & 0 & 1 \\
\hline & non- & 1796 & 18.06 & & 0.127 \\
\hline \multirow[t]{4}{*}{ pensions } & borrower & 1 & $\%$ & 0.0085 & 5 \\
\hline & & 1819 & 18.33 & & 0.067 \\
\hline & borrower & 8 & $\%$ & 0.0053 & 2 \\
\hline & non- & 2197 & 22.10 & & 0.177 \\
\hline \multirow[t]{4}{*}{ provisions } & borrower & 7 & $\%$ & 0.0147 & 8 \\
\hline & & 2225 & 22.42 & & 0.094 \\
\hline & borrower & 9 & $\%$ & 0.0080 & 0 \\
\hline & $\begin{array}{l}\text { non- } \\
\text { borrower }\end{array}$ & 3028 & $3,04 \%$ & 0 & $\begin{array}{l}0.032 \\
9\end{array}$ \\
\hline
\end{tabular}




\begin{tabular}{|c|c|c|c|c|c|}
\hline & & $\mathbf{N}$ & $\%$ & $10 \mathrm{P}$ & 99P \\
\hline \multirow{6}{*}{ short-term provisions } & & & & & 0.020 \\
\hline & borrower & 3220 & $3,24 \%$ & 0 & 3 \\
\hline & non- & 1863 & 18,74 & & 0.141 \\
\hline & borrower & 3 & $\%$ & 0.0089 & 2 \\
\hline & & 1995 & 20,10 & & 0.071 \\
\hline & borrower & 5 & $\%$ & 0.0055 & 5 \\
\hline \multirow[t]{2}{*}{ items of accounting policy included in tax_first } & & $\mathbf{N}$ & $\%$ & 90P & 99P \\
\hline & non- & & & & 0.052 \\
\hline \multirow[t]{3}{*}{ other long-term deferred costs } & borrower & 9193 & $9,24 \%$ & 0 & 2 \\
\hline & & 1593 & 16,05 & & 0.073 \\
\hline & borrower & 0 & $\%$ & 0.0019 & 1 \\
\hline \multirow{3}{*}{ short-term deferred costs } & non- & 8255 & 83,01 & & 0.287 \\
\hline & borrower & 1 & $\%$ & 0.0429 & 7 \\
\hline & & 8863 & 89,28 & & 0.250 \\
\hline \multirow{4}{*}{ other accruals (unearned revenue, deferred revenue) } & borrower & 9 & $\%$ & 0.0377 & 3 \\
\hline & non- & 4090 & 41,14 & & 0.494 \\
\hline & borrower & 8 & $\%$ & 0.0710 & 2 \\
\hline & & 5229 & 52,67 & & 0.426 \\
\hline \multirow{4}{*}{ long-term other accruals } & borrower & 1 & $\%$ & 0.0904 & 4 \\
\hline & non- & 1154 & 11,61 & & 0.247 \\
\hline & borrower & 6 & $\%$ & 0.0018 & 4 \\
\hline & & 2537 & 25,56 & & 0.290 \\
\hline \multirow{5}{*}{ short-term other accruals } & borrower & 4 & $\%$ & 0.0439 & 1 \\
\hline & non- & 3276 & 32,95 & & 0.347 \\
\hline & borrower & 5 & $\%$ & 0.0291 & 0 \\
\hline & & 4242 & 42,73 & & 0.252 \\
\hline & borrower & 1 & $\%$ & 0.0237 & 2 \\
\hline
\end{tabular}

\section{Conclusions}

This paper investigated how bank lending affects the link between tax law and the accounting income, and the extent to which their financial results and taxable income mirror each other (measured by book-tax conformity), focusing on Polish private SMEs complying with local GAAP in 2003-2013. The results offer compelling evidence that private firms recognize more conforming income when they are larger, more indebted to non-bank creditors, profitable and more indebted to the bank (except for the permanent book-tax differential) and have more tangible assets. Decreases in the book-tax conformity appear significantly related to the use of more advanced accounting practices by profitable borrowers, adhering to the prudence principle and the matching principle (more for the temporary and permanent booktax differential). These allow bank-lenders to learn more about a borrower's future cash flows, creditworthiness and ability to repay the bank loan. The findings indicate that debt financing provided by banks influence the book-tax conformity of private SMEs in Poland. However, the findings indicate that lenders are not constantly interested in high book-tax conformity. The insignificant relationship between bank debt and book-tax conformity of unprofitable borrowers indicate that bank-lenders demand higher informative earnings when borrowers generate financial losses than in the case of profitable borrowers, at least to some extent. On the other hand, in the case of profitable firms, bank lending increases their book-tax conformity. Tax avoidance applied by borrowers has a lower impact on book-tax differential than in the case of non-borrowers. 
Moreover, these findings confirm that monitoring by lenders forces companies to adopt more advanced accounting practices than non-borrowers, in particular, by the use of accounting standards, adhering to the prudence principle and the matching principle. These allow lenders to learn more about a borrower's ability to repay the bank loan thanks to more informative earnings. However, the main constraint is that only $22.5 \%$ of borrowers applied accounting standards, adhering to the prudence principle and the matching principle, that are not recognized by tax law, whereas the coefficient at the variable which measures recognizing and recording business operations in accordance with tax rules is lower in the case of borrowers, irrespective of the model. This indicates that borrowers recognize business operations less according to tax law, contrary to non-borrowers.

My findings contribute to recent research on the relationship between book-tax conformity and corporate capital structure (Blaylock et al., 2016) by indicating the different impact of bank debt on the book-tax conformity of borrowers rather than non-bank borrowings. My research outcomes are relevant for the ongoing discussion on the advantages of book-tax conformity, which include dampening earnings management, and causing a decrease in the use of corporate tax shelters and other tax avoidance activities (Graetz, 2005; Chan et al., 2010).

To conclude, I see several areas for improving accounting practices in the Polish market. Firstly, lowering the threshold for the mandatory keeping of accounts should increase the number of enterprises maintaining accounting books. This is important for countries such as Poland, where internal reporting systems are underdeveloped, as the financial accounting system may perform a highly influential role in guiding business decisions (Cascino et al., 2014). Secondly, increasing the role of the accounting system could help companies to benefit from better access to external finance, and monitoring by lending banks and, as a consequence, higher lender demand for more informative earnings could force companies to adopt more advanced accounting practices. Sources of funding are an essential issue for enterprises, especially SMEs: because of the limited availability of external capital, the enterprises invest less, do not use leverage, and grow more slowly (Rajan \& Zingales, 1995). 


\section{References}

Ali, A., \& Hwang, L. (2000) "Country-specific factors related to financial reporting and the value relevance of accounting data", Journal of Accounting Research, vol. 38 , no. 1: 1-21

Armstrong, Ch. S., Blouin J. L., \& Larcker, D.F. (2012) "The incentives for tax planning", Journal of Accounting and Economics, vol. 53, no. 1-2: 391-411

Armstrong, Ch. S., Guay, W. R., \& Weber, J. P. (2010) "The role of information and financial reporting in corporate governance and debt contracting", Journal of Accounting and Economics, vol. 50, no. 2-3: 179-234

Atwood, T. J., Drake, M. S., \& Myers, L. A. (2010) "Book-tax conformity, earnings persistence and the association between earnings and future cash flows", Journal of Accounting and Economics, vol. 50, no. 1: 111-125

Atwood, T.J., Drake, M.S., Myers, J.N., \& Myers, A. (2012) "Home Country Tax System Characteristics and Corporate Tax Avoidance: International Evidence", The Accounting Review, vol. 87, no. 6: 1831-1860

Balcerowicz, E., Balcerowicz, L., \& Hashi, I. (eds.) (1998) "Barriers to Entry and Growth of Private Companies in Poland, the Czech Republic, Hungary, Albania and Lithuania", CASE Working Paper, no. 14

Ball, R., \& Shivakumar, L. (2005) "Earnings quality in UK private firms: comparative loss recognition timeliness", Journal of Accounting and Economics, vol. 39, no. 1: 83-128

Baltagi, B. H., \& Wu, P. X. (1999) "Unequally spaced panel data regressions with AR(1) disturbances", Econometric Theory, vol. 15, no. 6: 814-823

Bank Pekao SA (2016) "Raport o sytuacji mikro i małych firm w roku 2016" [Report on the situation of micro and small businesses in 2016], available on-line at: https://www.pekao.com.pl/mis/raport_SME/

Beck, T., \& Demirguc-Kunt, A. (2006) "Small and medium-size enterprises: Access to finance as a growth constraint", Journal of Banking and Finance, vol. 30, no. 11: 2931-2943

Begley, J., \& Freeman, R. (2004) "The changing role of accounting numbers in public lending agreements", Accounting Horizons, vol. 18, no. 2: 81-96

Białek-Jaworska, A., \& Drązikowska, K. (2015) "Polityka rachunkowości spółek notowanych na NewConnect" [Accounting policy of companies listed on NewConnect], Research Papers of the Wroclaw University of Economics, vol. 390: 55-63

Białek-Jaworska, A., \& Matusiewicz, A. (2015) "Determinants of the level of information disclosure in financial statements prepared in accordance with IFRS", Accounting and Management Information Systems, vol. 14, no. 3: 453482

Białek-Jaworska, A., \& Nehrebecka, N. (2016) "The role of bank credit in business financing in Poland", Faculty of Economic Science University of Warsaw Working Paper, no. 3(193) 
Bijlsma, M.J., \& Zwart, G.T.J. (2013) "The changing landscape of financial markets in Europe, the United States and Japan", CPB Discussion Paper, no. 238

Bikky, J., \& Picheng, L. (2002) "Earnings management in response to debt covenant violations and debt re-structuring", Journal of Accounting, Auditing and Finance, vol. 17, no. 4: 295-324

Black, F., \& Scholes, M. (1973) "The pricing of options and corporate liabilities", Journal of Political Economy, vol. 81, no. 3: 637-654

Blaylock, B., Gaertner, F., \& Shevlin, T. (2016) "Book-tax Conformity and Capital Structure", Working Paper, Retrieved from http://dx.doi.org/10.2139 /ssrn.2437196

Cascino, S., Clatworthy, M., Garcia Osma, B., Gassen, J., Imam, S., \& Jeanjean, T. (2014) "Who Uses Financial Reports and for what Purpose? Evidence from Capital Providers", Accounting in Europe, vol. 11, no. 2: 185-209

Chan, K. H., Lin, K. Z., \& Mo, P.L.L. (2010) "Will a departure from tax-based accounting encourage tax noncompliance? Archival evidence from a transition economy", Journal of Accounting and Economics, vol. 50, no. 1: 58-73

Chua, J. H., Chrisman, J. J., Kellermanns, F., \& Wu, Z. (2011) "Family involvement and new venture debt financing", Journal of Business Venturing, vol. 26, no. 4: $472-488$

Coluzzi, C., Ferrando, A., \& Martinez-Carrascal, C. (2012) "Financing obstacles and growth: An analysis for Euro Area non-financial firms", European Journal of Finance, vol. 18, no. 3: 1-18

Dechow, P. (1994) "Accounting earnings and cash flows as measures of firm performance: the role of accounting accruals", Journal of Accounting and Economics, vol. 18, no. 1: 3-42

Dobbs, R., Lund, S., Woetzel, J., \& Mutafchieva, M. (2015) Debt and (not much) deleveraging, McKinsey Global Institute, available on-line at: http://www.mckinsey.com/global-themes/employment-and-growth/debt-andnot-much-deleveraging

Easton, P., Monahan, S., \& Vasvari, F. (2009) "Initial evidence on the role of accounting earnings in the bond market", Journal of Accounting Research, vol. 47, no. 3: 721-766

Gavana, G., Guggiola, G., \& Marenzi, A. (2013) "Evolving Connections Between Tax and Financial Reporting in Italy", Accounting in Europe, vol. 10, no. 1: 43-70

Gee, M., Haller, A., \& Nobes, C. (2010) "The influence of tax on IFRS consolidated statements: the convergence of Germany and the UK", Accounting in Europe, vol. 7, no. 1: 97-122

Gomułka, S. (1993) The Financial Situation of Polish Enterprises 1992-93 and its Impact on Monetary and Fiscal Policies, CASE, Warsaw

Grabinski, K. (2016) "Wpływ kryzysu gospodarczego na aktywne kształtowanie wyniku finansowego w europejskich spółkach giełdowych" [Impact of economic crisis on earnings management in European listed companies], Zeszyty Teoretyczne Rachunkowości, vol. 87, no. 143: 29-42 
Graetz, M. (2005) A fair and balanced tax system for the twenty-first century, Toward Fundamental Tax Reform: 48-69, Edited by Alan Auerbach and Kevin Hassett, The AEI Press, Washington DC

Guay, W., Kothari, S. S. P., \& Watts, R. L. (1996) "A market-based evaluation of discretionary accruals", Journal of Accounting Research, vol. 34, no. 3: 83-105

Guenther, D. A., \& Sansing, R. C. (2004) "The valuation relevance of reversing deferred tax liabilities", The Accounting Review, vol. 79, no. 2: 437-451

GUS (2015) Działalność przedsiębiorstw niefinansowych w 2013 r. [Central Statistical Office (CSO) (2015), Non-financial corporate activity in 2013], Warszawa

Hanlon, M., \& Heitzman, S. (2010) "A Review of tax research", Journal of Accounting and Economics, vol. 50, no. 2-3: 127-178

Hanlon, M., Maydew, E. L., \& Shevlin, T. (2008) "An unintended consequence of book-tax conformity: A loss of earnings informativeness", Journal of Accounting and Economics, vol. 46, no. 2/3: 294-311

Hanlon, M., Laplante, S. K., \& Shevlin, T. (2005) "Evidence for the possible information loss of conforming book income and taxable income", Journal of Law and Economics, vol. 48, no. 2: 407-442

Hope, O.K. (2003) "Disclosure practices, enforcement of accounting standards, and analysts, forecast accuracy: An international study", Journal of accounting research, vol. 41, no. 2: 235-272

Hussain, A. (1994) "Private Sector Development in Economies in Transition", Journal of Comparative Economics, vol. 19, no. 2: 260-271

IMF, Sahay, R., Čihák, M., N’Diaye, P., Barajas, A., Bi, R., Ayala, D., Gao, Y., Kyobe, A., Nguyen, L., Saborowski, Ch., Svirydzenka, K., \& Yousefi, R. S. (2015) "Rethinking Financial Deepening: Stability and Growth in Emerging Markets", International Monetary Fund, IMF Staff Discussion Note, no. SDN/15/08, available on-line at: https://www.imf.org/external/ pubs/ft/sdn/2015/sdn1508.pdf

Jensen, M., \& Meckling, W. (1976) "Theory of the firm: Managerial behavior, agency costs and ownership structure", Journal of Financial Economics, vol. 3, no. 4: 305-360

Kozarzewski, P., Radziwiłł, A., \& Walewski, M. (2004) Country Paper: Poland, International Policy Conference on Transition Economies, Hanoi, Vietnam, 31 May-1 June, 2004, UNDP, from archival materials of CASE, Warsaw: CASE

Kvaal, E., \& Nobes, Ch. (2012) "On the definition and measurement of book-tax conformity", Working Paper, University of London

Laux, R. C. (2013) "The Association between Deferred Tax Assets and Liabilities and Future Tax Payments", The Accounting Review, vol. 88, no. 4: 1357-1383

Nobes, C. W. (2008) "Accounting classification in the IFRS Era", Australian Accounting Review, vol. 18, no. 3: 191-197 
Nowak, W. A. (2015) "The evolution of governmental accounting in the phases of a State regime reshaping from capitalism to socialism and from socialism to capitalism: the case of Poland in the 1950s - mid-1990s", Theoretical Journal of Accounting (Zeszyty Teoretyczne Rachunkowości), vol. 84, no. 140: 159-180

Plummer, E., \& Tse, S. (1999) "The effect of limited liability on the informativeness of earnings: Evidence from the stock and bond markets", Contemporary Accounting Research, vol. 16, no. 3: 541-574

Rajan, R. G., \& Zingales, L. (1995) "What do we know about capital structure? Some evidence from international data", The Journal of Finance, vol. 50, 5: 1421-1460

Richardson, G., Wang, B., \& Zhang, X. (2016) "Ownership structure and corporate tax avoidance: Evidence from publicly listed private firms in China", Journal of Contemporary Accounting \& Economics, vol. 12, no. 2: 141-158

Schoenmaker, D., \& Wagner, W. (2011) The Impact of Cross-Border Banking on Financial Stability. Discussion Paper, TI 11-054 / DSF 18, Duisenberg School of Finance, Tinbergen Institute

Siudaj, M. (2015) "MG: Rekordowa liczba jednoosobowych działalności gospodarczych" [MG: Record number of one-man business activities], available on-line at: http://biznes.interia.pl/firma/news/rekordowa-liczbajednoosobowych-dzialalnosci-gospodarczych, 2139102,1852 [9 March 2017]

Sweeney, P. (1994) 'Debt-covenant violations and managers' accounting responses", Journal of Accounting and Economics, vol. 17, no. 3: 281-308

Tang, T., \& Firth, M. (2011) "Can book-tax differences capture earnings management and tax management? Empirical evidence from China", The International Journal of Accounting, vol. 46, no. 2: 175-204

Tang, T., \& Firth, M. (2012) "Earnings persistence and stock market reaction to the different information in book-tax differences: Evidence from China", The International Journal of Accounting, vol. 47, no. 3: 369-397

Tang, T. (2015) "Does Book-Tax Conformity Deter Opportunistic Book and Tax Reporting? An International Analysis", European Accounting Review, vol. 24, no. 3: 441-469

Watrin, C., Ebert, N., \& Thomsen, M. (2012) "One-book versus two-book system: Leaning from Europe", University of Muenster Working Paper, retrieved from https://papers.ssrn.com/sol3/papers.cfm?abstract_id=2111517

Watrin, Ch., Ebert, N., \& Thomsen, M. (2014) "Book-Tax Conformity and Earnings Management: Insights from European One- and Two-Book Systems", The Journal of the American Taxation Association, vol. 36, no. 2: 55-89

Wilson, R. J. (2009) "An examination of corporate tax shelter participations", The Accounting Review, vol. 84, no. 3: 969-999

ZBP (2015) Polska i Europa - wyzwania i zagrożenia [Poland and Europe challenges and threats], Warszawa: Związek Banków Polskich

Accounting Act of 29 September 1994, Journal of Laws of 2013, points 330 and 613 